\title{
AN ANALYSIS OF SALINITY IN STREAMS OF THE GREEN RIVER BASIN, WYOMING
}

U.S. GEOLOGICAL SURVEY
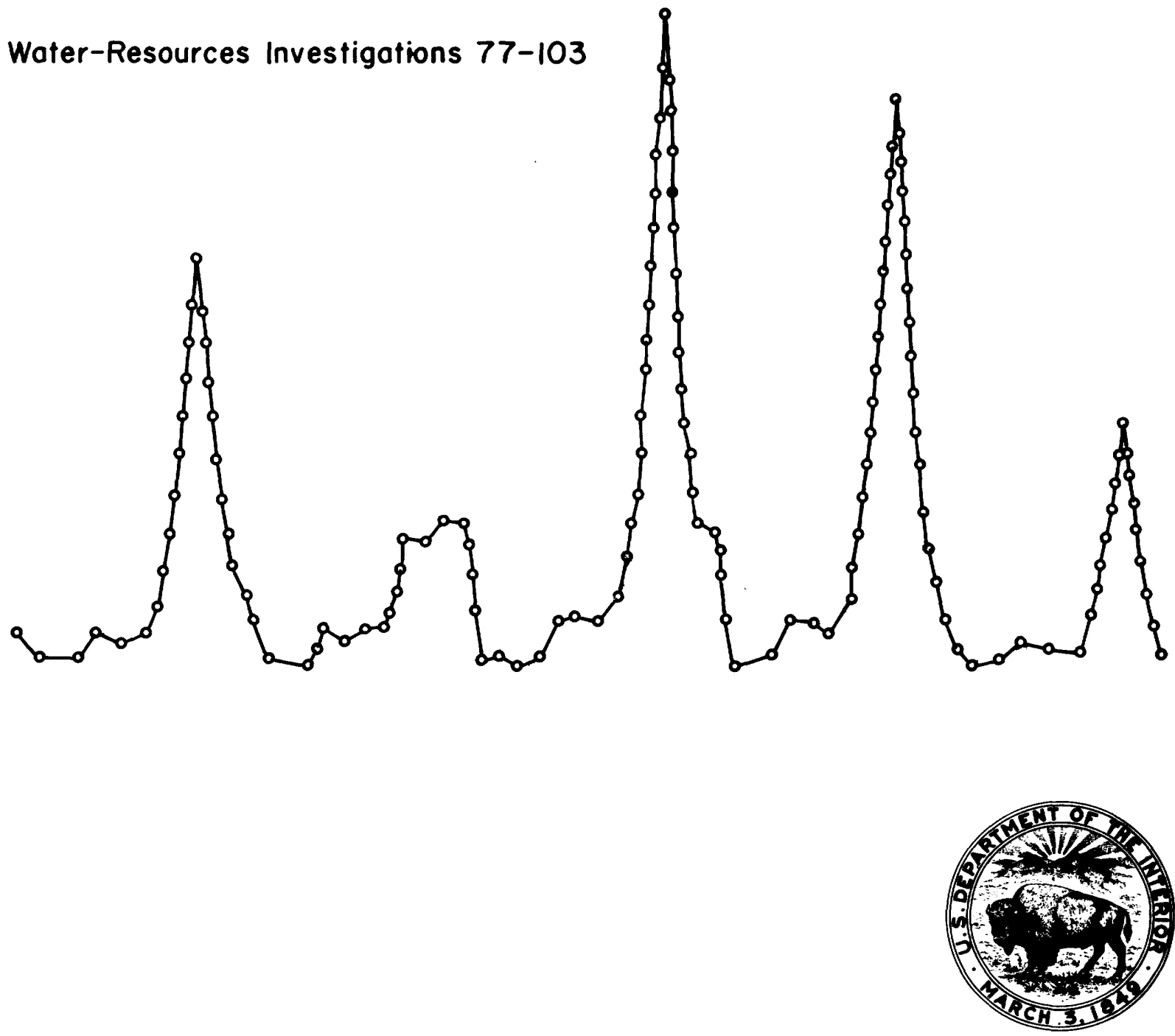


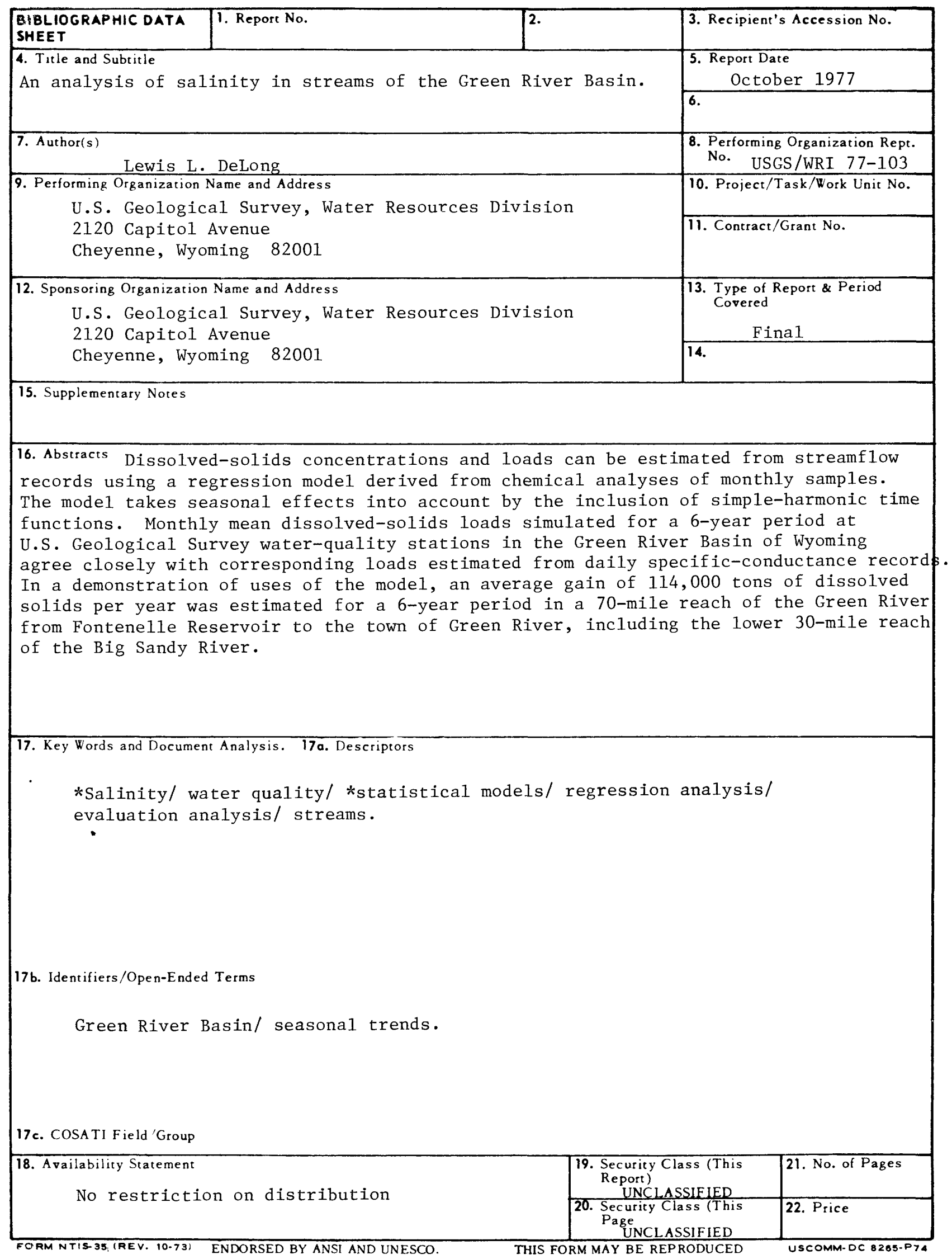


AN ANALYSIS OF SALINITY IN STREAMS OF THE

GREEN RIVER BASIN, WYOMING

By Lewis L. DeLong

U.S. GEOLOGICAL SURVEY

Water-Resources Investigations 77-103

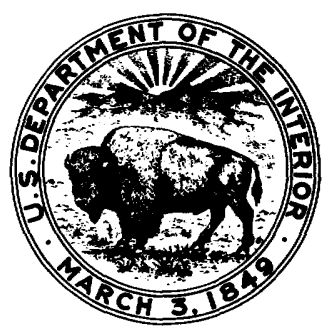

September 1977 
UNITED STATES DEPARTMENT OF THE INTERIOR

CECIL D. ANDRUS, Secretary

GEOLOGICAL SURVEY

V. E. McKelvey, Director

For additional information write to:

U.S. Geological Survey

2120 Capitol Avenue,

P.0. Box 1125

Cheyenne, Wyoming 82001 
Abstract--_-

Introduction-_-_-_- 1

Purpose--

Data analyzed-C- 3

Method of analysis--_-_-_- 3

Two-variable regression mode1-_- 6

Multiple-variable regression model-_-_- 9

Application of the multiple-variable regression mode1------------- 11

Computation of monthly mean dissolved-solids loads--------- 11

Delineation of sources of salinity- 21

Summary-_-

Selected references-_-_- 28

\section{ILLUSTRATIONS}

Figure 1. Map showing location of the Green River Basin in Wyoming

2. Map showing locations of quality-of-water sampling stations

3-6. Graphs showing--

3. Relation of dissolved solids to discharge at station 09188500 Green River at Warren Bridge, near Daniel, Wyoming--

4. Difference between dissolved-solids concentrations estimated from the two-variable-regression model and dissolved-solids concentrations observed at station 09188500 Green River at Warren Bridge, near Daniel, Wyoming----------

5. Difference between dissolved-solids concentrations estimated from the multiple-variable-regression model and dissolved-solids concentrations observed at station 09188500 Green River at Warren Bridge, near Daniel, Wyoming--

6. Relation of dissolved-solids concentration to specific conductance at station 09188500 Green River at Warren Bridge, near Daniel, Wyoming-- 


\section{ILLUSTRATIONS--continued}

Figure 7-14. Graphs showing month1y mean dissolved-solids loads, 1970-75 water years:

7. Station 09188500 Green River at Warren Bridge, near Danie1, Wyoming- 13

8. Station 09205000 New Fork River near Big Piney, Wyoming- 14

9. Station 09209400 Green River near La Barge, Wyoming- 15

10. Station 09211200 Green River below Fontenelle Reservoir, Wyoming- 16

11. Station 09216000 Big Sandy River below Eden, Wyoming-_- 17

12. Station 09217000 Green River near Green River, Wyoming-_- 18

13. Station 09222000 Blacks Fork near Lyman, Wyoming- 19

14. Station 09224700 Blacks Fork near Little America, Wyoming- 20

15-18. Graphs showing:

15. Cumulative dissolved-solids loading in reaches enclosed by stations 09211200 Green River below Fontenelle Reservoir, Wyoming; 09216000 Big Sandy River below Eden, Wyoming; and 09217000 Green River near Green River, Wyoming-_-_-

16. Cumulative dissolved-sodium loading in reaches enclosed by stations 09211200 Green River below Fontenelle Reservoir, Wyoming; 09216000 Big Sandy River below Eden, Wyoming; and 09217000 Green River near Green River, Wyoming 
Figure 15-18. Graphs showing:--continued

17. Cumulative dissolved-sulfate loading in reaches enclosed by stations 09211200 Green River below Fontenelle Reservoir, Wyoming; 09216000 Big Sandy River below Eden, Wyoming; and 09217000 Green River near Green River, Wyoming-

18. Sum of dissolved-sodium and dissolved-sulfate annual loads versus dissolved-solids annual loads for estimated seepage and stations 09211200 Green River below Fontenelle Reservoir, Wyoming; 09216000 Big Sandy River below Eden, Wyoming; and 09217000 Green River near Green River, Wyoming-------

TABLES

Table 1. Chemical quality-of-water sampling stations---------- 5

2. Sequence number conversion, date to water-year day----- 29

3. Regression results, concentration versus discharge and time-- 30

4. Regression results, concentration versus specific conductance 
CONVERSION FACTORS

Multiply English units

cubic feet per second $\left(\mathrm{ft}^{3} / \mathrm{s}\right)$

tons per day
By

0.02832

.9072
To obtain metric units

cubic meters per second $\left(\mathrm{m}^{3} / \mathrm{s}\right)$

megagrams per day $(\mathrm{Mg} / \mathrm{d})$ 
AN ANALYSIS OF SALINITY IN STREAMS OF THE

GREEN RIVER BASIN, WYOMING

by Lewis L. DeLong

\begin{abstract}
Dissolved-solids concentrations and loads can be estimated from streamflow records using a regression model derived from chemical analyses of monthly samples. The model takes seasonal effects into account by the inclusion of simple-harmonic time functions. Monthly mean dissolved-solids loads simulated for a 6-year period at U.S. Geological Survey water-quality stations in the Green River Basin of Wyoming agree closely with corresponding loads estimated from daily specific-conductance records. In a demonstration of uses of the model, an average gain of 114,000 tons of dissolved solids per year was estimated for a 6-year period in a 70-mile reach of the Green River from Fontenelle Reservoir to the town of Green River, including the lower 30-mile reach of the Big Sandy River.
\end{abstract}

\title{
INTRODUCTION
}

Water demands in the Green River Basin of Wyoming (fig. 1) are Increasing as a result of existing and potential development of extensive coal, oll, gas, uranium, and oil-shale resources. Planners need more useable information than is now available concerning the effects of proposed development alternatives on the water resources of the basin (Lowham and others, 1976). Water quality, specifically salinity, is an important factor in determining water use and in assessing possible impacts of those uses over time. Salinity data have been collected on the Green River and its major tributaries during the last 25 years, but use of the data in tabular form as published has been limited. A quantitative description of salinity in the Green River and its major tributaries is useful to the evaluation of alternative development plans. 

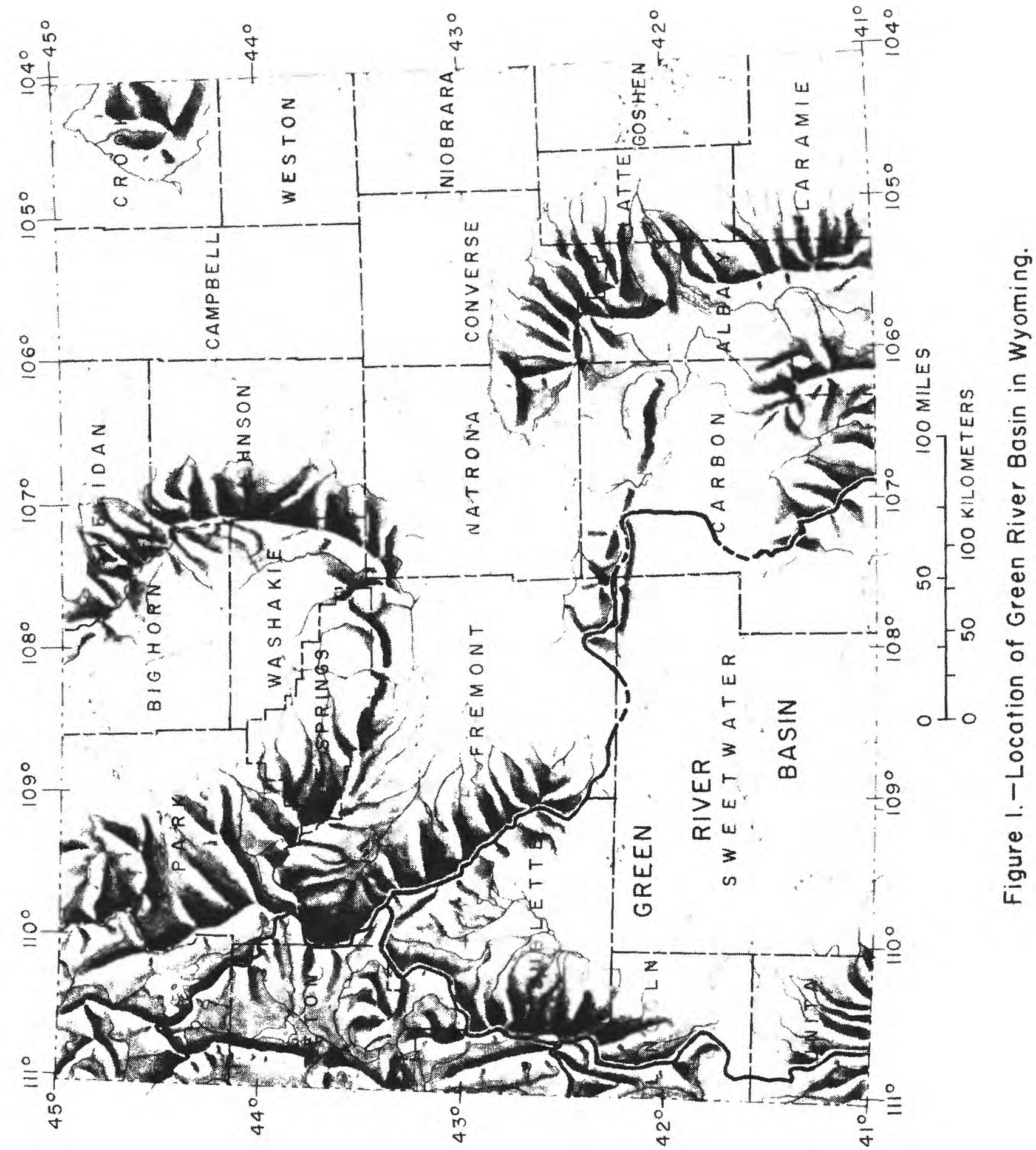


\section{Purpose}

The purpose of this report is to present a method for converting salinity data into more useable information. Specific objectives are to develop and demonstrate a regression model that would enable daily concentrations and monthly and annual mean loads of the major dissolved inorganic constituents to be estimated at streamflow stations where only monthly samples have been collected.

\section{Data Analyzed}

Data analyzed in this report are from streamflow and water-quality stations operated by the U.S. Geological Survey in cooperation with other Federal agencies and with the State of Wyoming. Station locations are shown in figure 2. Table 1 lists sampling stations and period of record for which data were analyzed. In general, the data include analyses of the major inorganic constituents from discrete samples collected before October 1975. Several of the stations have historical water-quality records available in addition to the data used for this study.

\section{METHOD OF ANALYSIS}

A quantitative description of the solutes transported in a stream system is useful to evaluate the impacts of proposed or past surfacewater development projects (such as reservoirs, irrigation systems, and withdrawals for municipal or industrial use). Many published waterquality records consist of analyses of monthly samples. Natural variability of streamflow during a month reduces the value of a discrete sample to represent streamflow quality throughout the entire month. When daily streamflow records are available in addition to monthly water-quality records, an improved representation of streamflow quality throughout the month may be obtained from estimates that utilize functional relations between streamflow and solute concentration. Multiple-variable regression is used in this report to define the relation of solute concentration to streamflow and day of the year. 


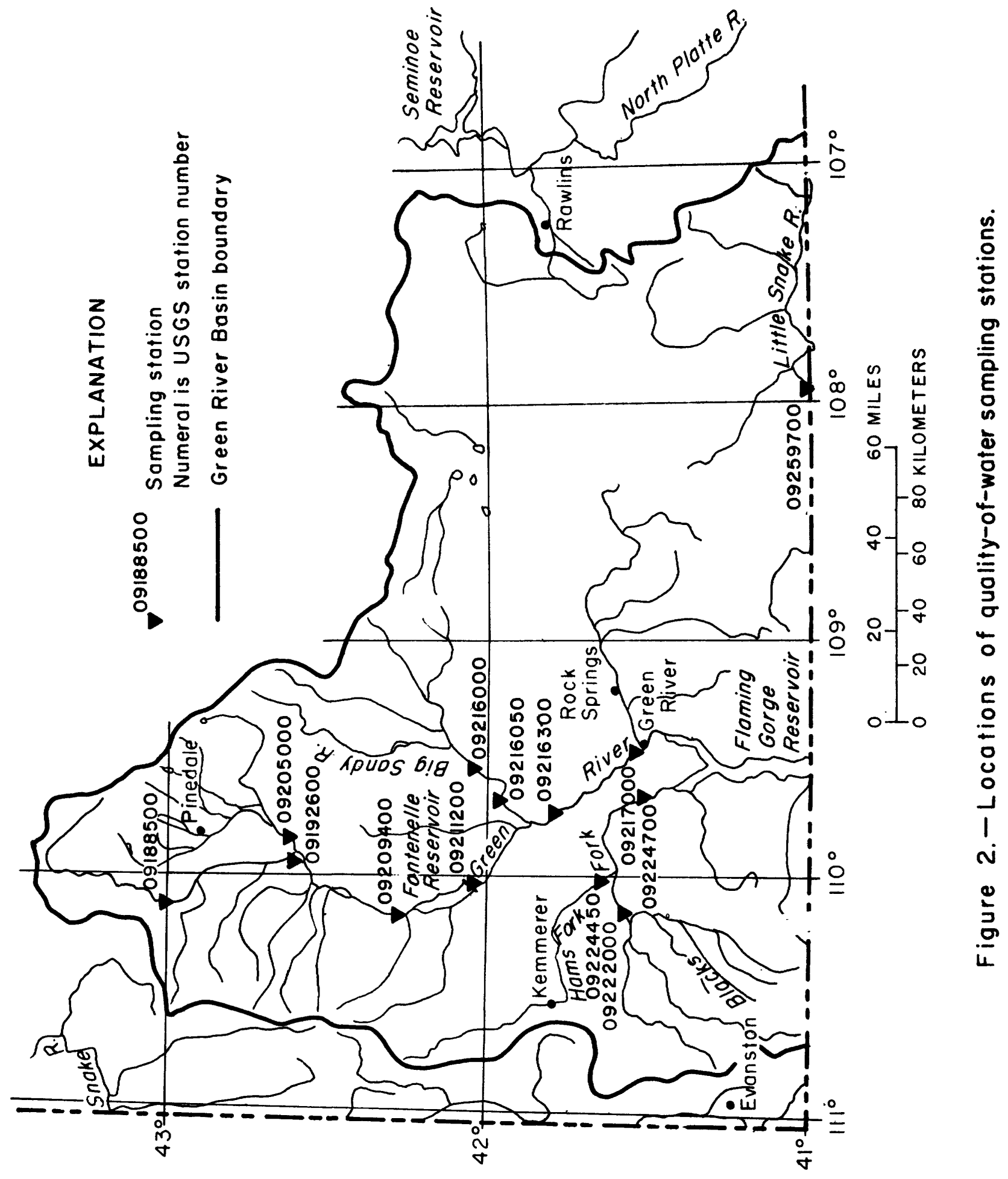


Table 1.--Chemical quality-of-water sampling stations

in Wyoming

[See fig. 2 for locations.]

\begin{tabular}{|c|c|c|}
\hline Station & Name & $\begin{array}{c}\text { Water Years } \\
\text { analyzed }\end{array}$ \\
\hline 09188500 & Green River at Warren Bridge, near Daniel---- & $1968-75$ \\
\hline 09192600 & Green River near Big Piney-- & $1967-75$ \\
\hline 09205000 & New Fork River near Big Piney- & $1969-75$ \\
\hline 09209400 & Green River near La Barge--- & $1970-75$ \\
\hline 09211200 & Green River below Fontenelle Reservoir-- & $1970-75$ \\
\hline 09216000 & Big Sandy River below Eden-- & $1961-75$ \\
\hline 09216300 & Green River at Big Island, near Green River-- & $1966-75$ \\
\hline 09217000 & Green River near Green River- & $1969-75$ \\
\hline 09222000 & Blacks Fork near Lyman- & $1970-75$ \\
\hline 09224450 & Hams Fork near Granger-C & $1969-75$ \\
\hline 09224700 & Blacks Fork near Little America-- & $1970-75$ \\
\hline 09259700 & Little Snake River near Baggs-- & $1965-74$ \\
\hline
\end{tabular}

a/ Cooperators: U.S. Bureau of Land Management. Wyoming Department of Environmental Quality. Wyoming Department of Agriculture. U.S. Geological Survey. U.S. Bureau of Reclamation. 
Dissolved-solids concentration in a stream is related to many factors, but one of the most important is the volume of water available for dilution (Hem, 1970, p. 271). In general, higher concentrations occur at lower streamflows, and with increasing flows concentrations tend to decrease.

Concentration of the major dissolved inorganic constituents in a stream can be related to streamflow by the following two-variable regression equation (Steele, 1973 and 1976):

$$
\mathrm{C}=\mathrm{A} \mathrm{Q}^{\mathrm{B}}
$$

where

$$
\begin{aligned}
& C=\text { concentration, in milligrams per liter, } \\
& Q=\text { streamflow, in cubic feet per second, and }
\end{aligned}
$$

$\mathrm{A}$ and $\mathrm{B}=$ regression coefficients.

An example of this relation is shown in figure 3. Concentration residuals (differences between estimated and observed concentrations) shown in figure 4 are consistently positive during some periods and negative during other periods.

Seasonal shifts in the concentration-flow relation, as exemplified in figure 4, are typical of data for the stations analyzed in this report and, in general, limit the application of equation 1 to depict concentration-flow relations in the Green River Basin. The regression procedure, assuming a constant year-round relation, causes concentration residuals totaled over the entire regression period to approach zero. Positive residuals during one period are balanced against negative residuals during another period. Because streamflow is not evenly distributed over time, residuals from loads calculated from streamflow records and estimated concentrations will normally not approach zero. This leads to inaccuracies both in estimation of annual loads at a given site and seasonal distribution of the annual load over the year. 


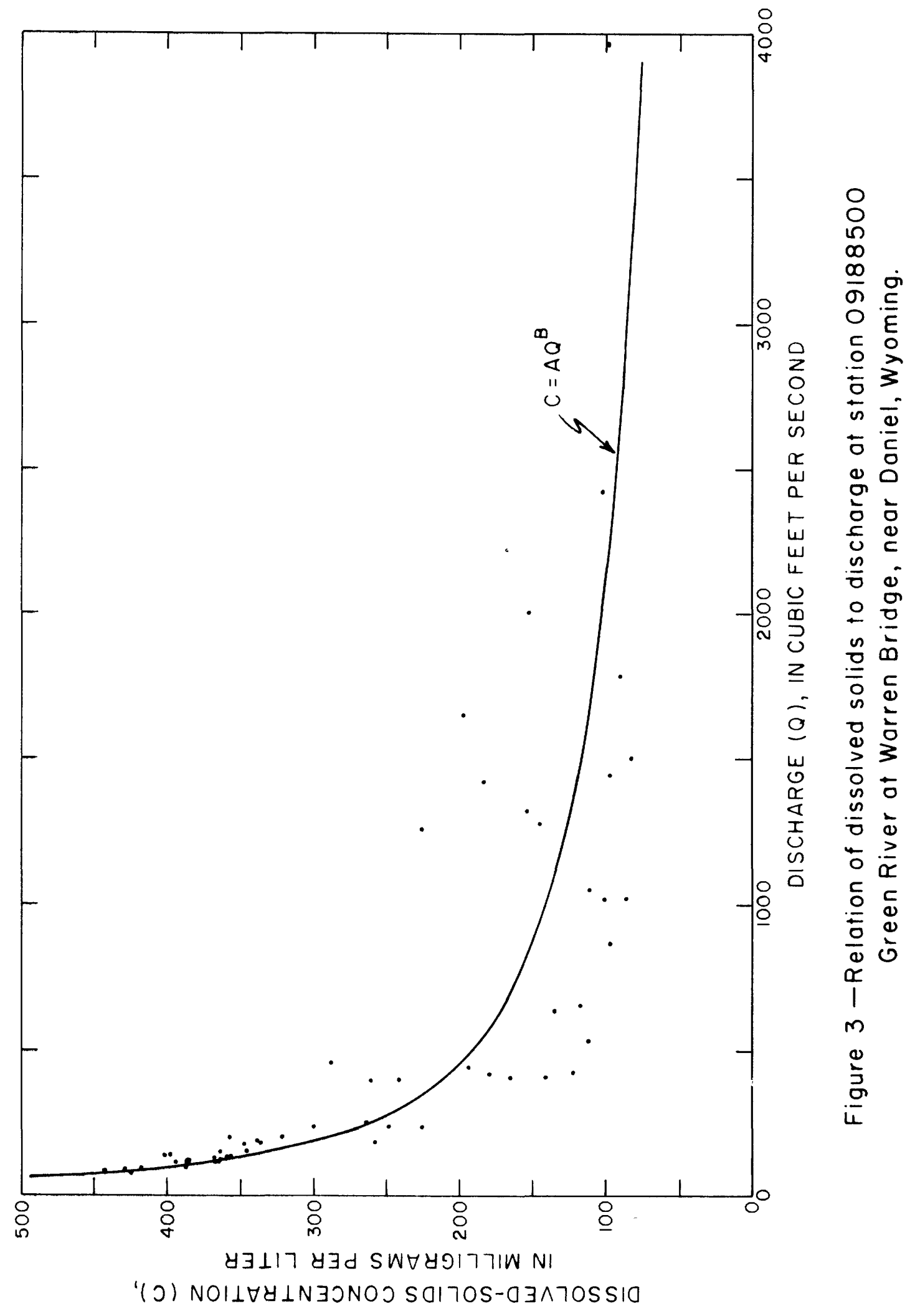




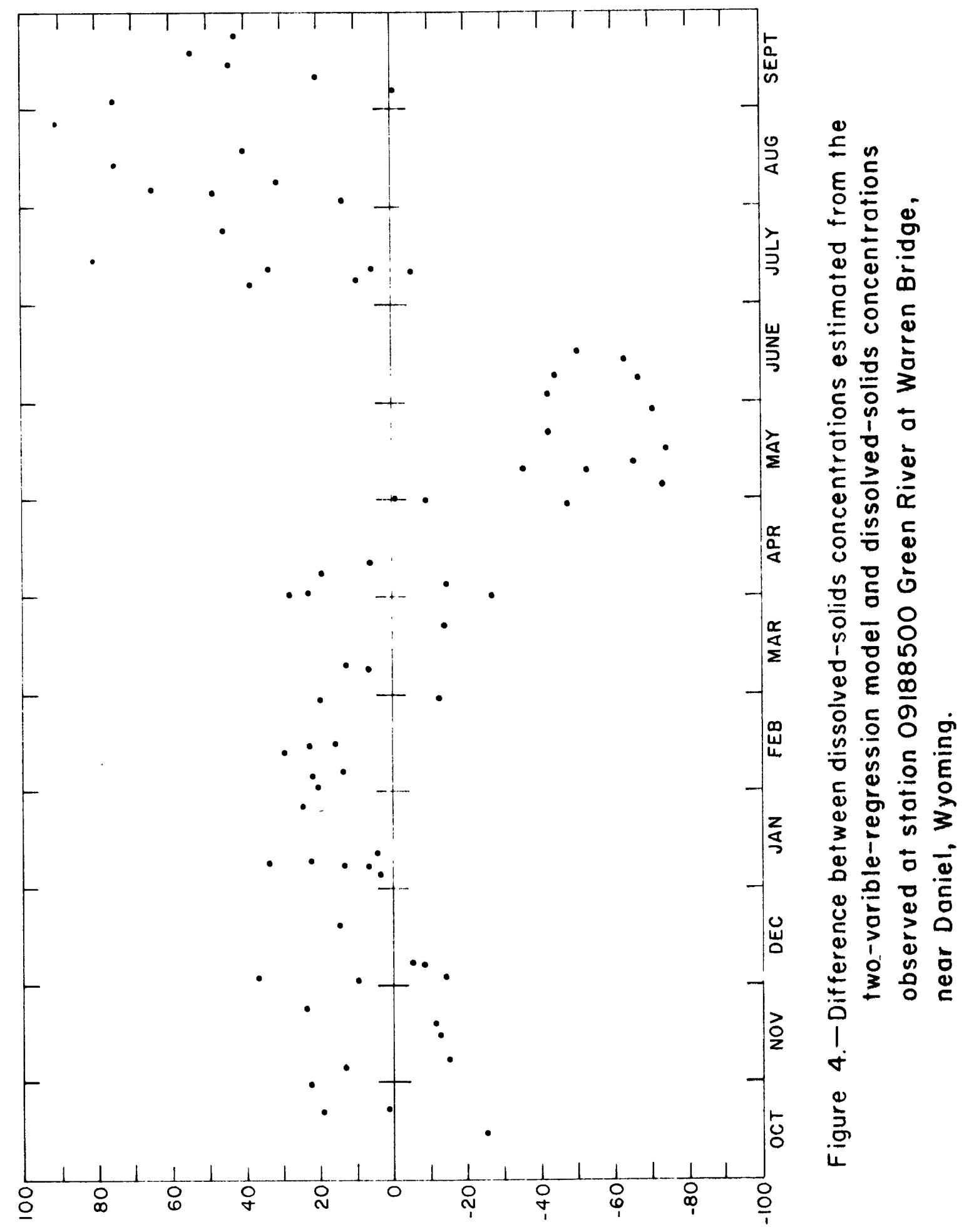

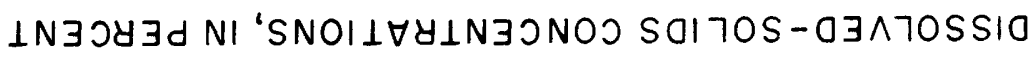

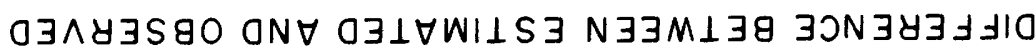


Seasonal effects were accounted for quantitatively by adding a season-related variable to the regression model. Water temperature would have been an obvious selection for this variable, but time, expressed as day of the water year (table 2), was used because it simplified later simulation efforts. Seasonal effects are incorporated into coefficients $A$ and $B$ in equation 1 by using the following functions:

$$
\begin{aligned}
\log _{10} A & =B_{0}+B_{1} \sin (\alpha t)+B_{2} \cos (\alpha t) \text { and } \\
B & =B_{3}+B_{4} \sin (\alpha t)+B_{5} \cos (\alpha t),
\end{aligned}
$$

where

$$
\text { where } \begin{aligned}
t & =\text { day of the water year (table } 2), \\
\alpha & =0.987 \text { degrees per day or } 0.0172 \text { radians per } \\
& \text { day, and } \\
B_{0} \text { through } B_{5}= & \text { regression coefficients (table } 3) .
\end{aligned}
$$

Parameters $B_{0}$ through $B_{5}$ were determined for the major dissolved inorganic constituents by a multiple-variable regression technique using a computer program developed by K. C. Glover (written commun., 1976). Regression-analysis results for the stations covered in this study are listed in table 3. To demonstrate the improved accuracy of the multipleregression model in describing variability of dissolved-solids concentration, residuals of the model are plotted versus time in figure 5 . This may be compared with the previous two-variable regression example (fig. 4). The same data for station 09188500 were used in both cases. Similar changes in terms of reduced magnitude and more random time-series distribution of residuals were found for other stations analyzed in this report. Hence, subsequent computations in this report utilize the model determined by the multiple-regression technique. 


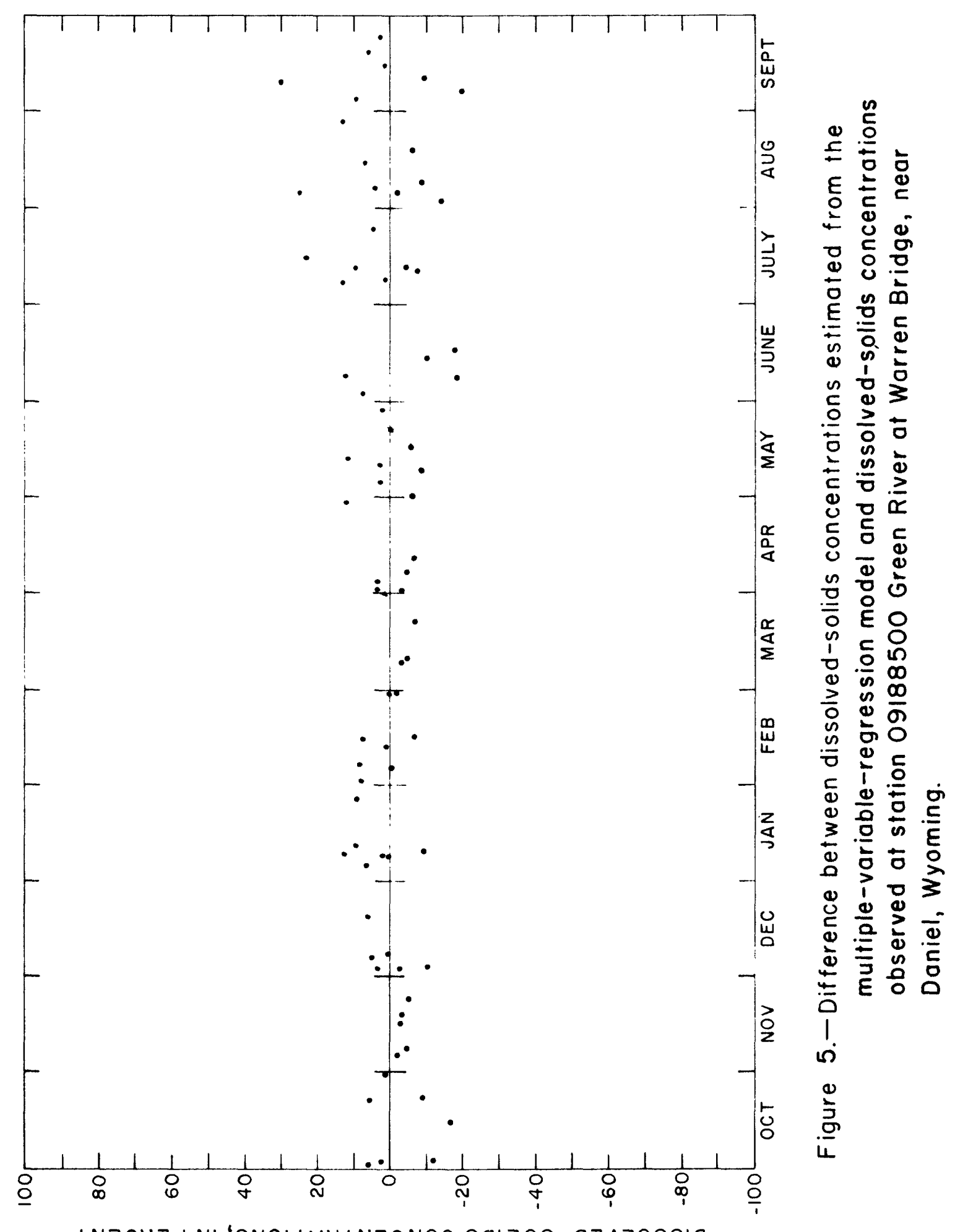

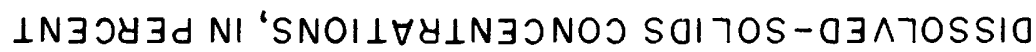

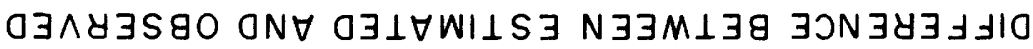




\section{Computation of Monthly Mean Dissolved-Solids Loads}

Monthly mean dissolved-solids loads can be computed from daily streamflow records using the multiple-variable regression model previously described to estimate daily concentrations in the following relation:

$$
\bar{L}=(b / d) \sum_{j=1}^{d} C_{j} Q_{j}
$$

where $\overline{\mathrm{L}}=$ monthly mean load, in tons per day,

$\mathrm{b}=0.0027$ (tons per day (milligram) (cubic feet per second),

$\mathrm{d}=$ days per month,

$\mathrm{j}=$ day of month,

$\mathrm{C}_{\mathrm{j}}=$ daily concentration, in milligrams per 1iter, and

$\mathrm{Q}_{\mathrm{j}}=$ daily discharge, in cubic feet per second.

Daily dissolved-solids concentrations can be estimated by another method when daily specific conductance data are available. Dissolvedsolids concentration can be related to specific conductance (fig. 6) by the following equation (Steele, 1973):

$$
C_{j}=E+F K
$$

where $\quad C_{\mathbf{j}}=$ daily dissolved-solids concentration, in milligrams

$E$ and $F=$ regression coefficients (table 4), and

$\mathrm{K}=$ specific conductance, in micromhos per centimeter at $25^{\circ} \mathrm{C}$.

Because of the large number of calculations involved in estimating dissolved-solids loads, equations 1 through 5 were incorporated into a computer program developed by K. C. Glover (written commun., 1976). Card output from the program was used with an off-1ine card reader and $\mathrm{X}-\mathrm{Y}$ plotter to produce solute-load hydrographs as exemplified for dissolved solids in figures 7-14. Individual constituent concentrations and loads (table 3) also can be estimated and plotted.

Semi-quantitative conclusions can be drawn from the dissolvedsolids-load hydrographs (figs. 7-14). At stations 09209400, 09211200, 09217000, 09222000, and 09224700 (figs. 9, 10, 12, 13, and 14) where daily specific-conductance data are available, generally good agreement exists between loads computed from concentrations estimated by the two previously described methods. Because identical scales are used on the 


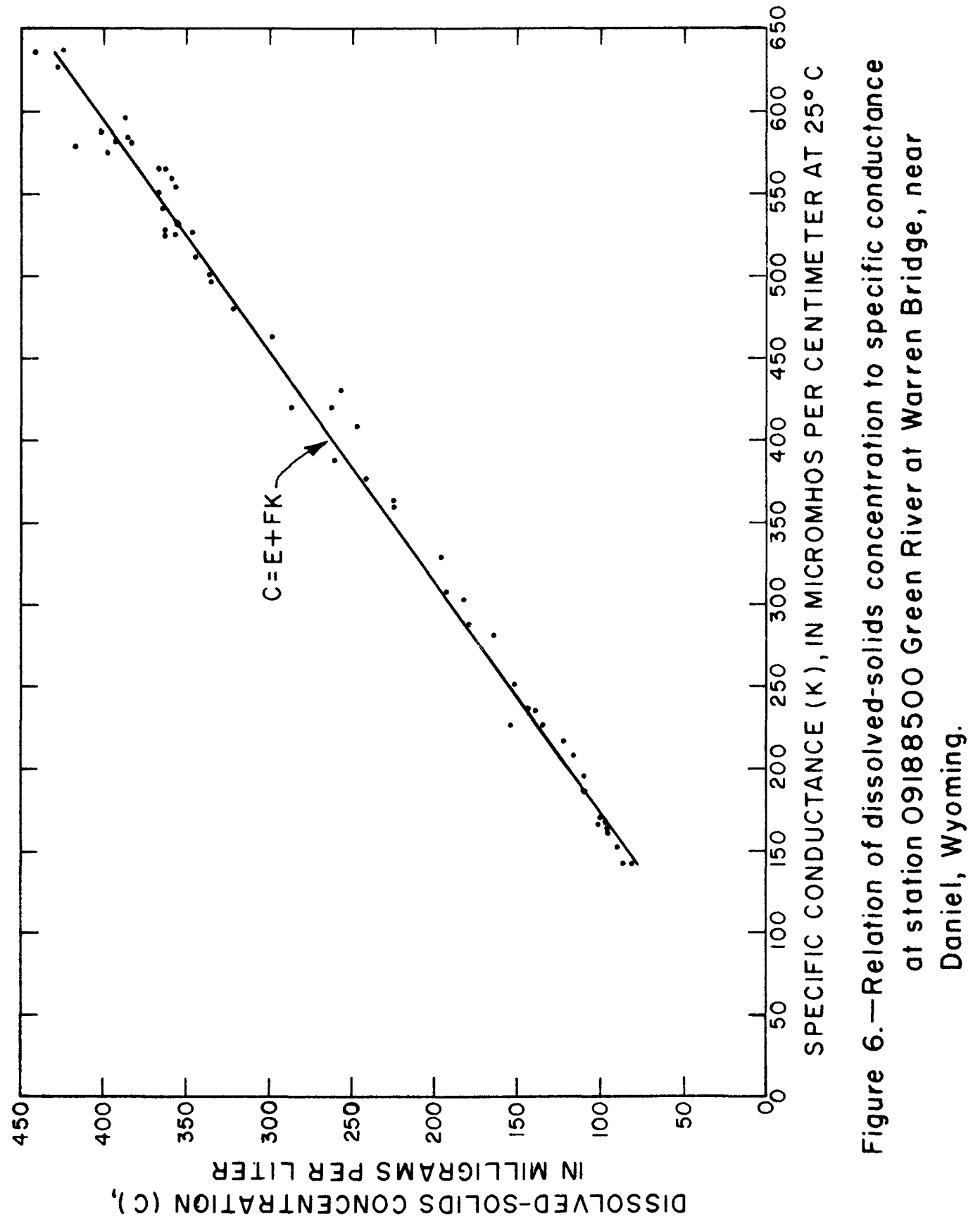




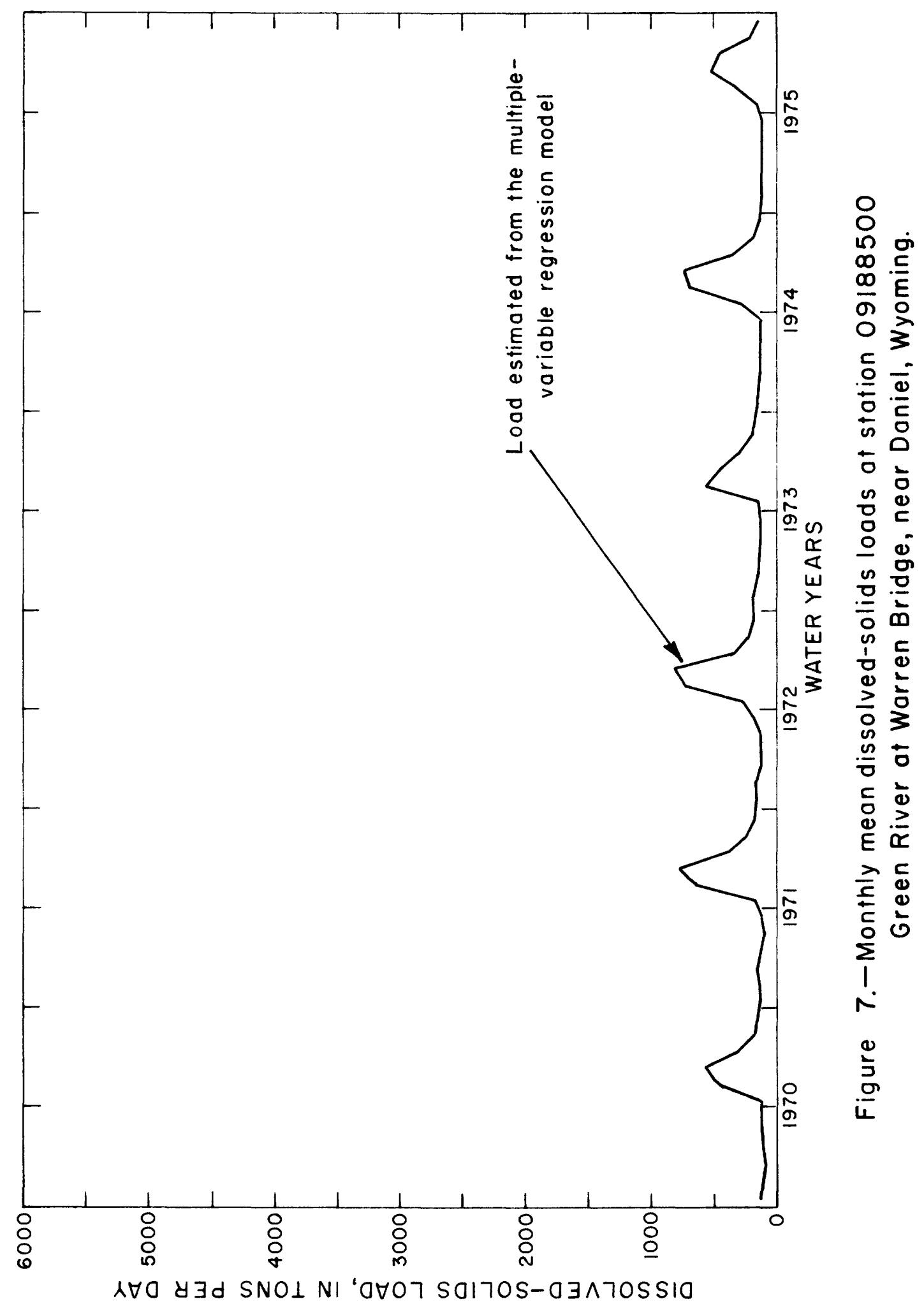




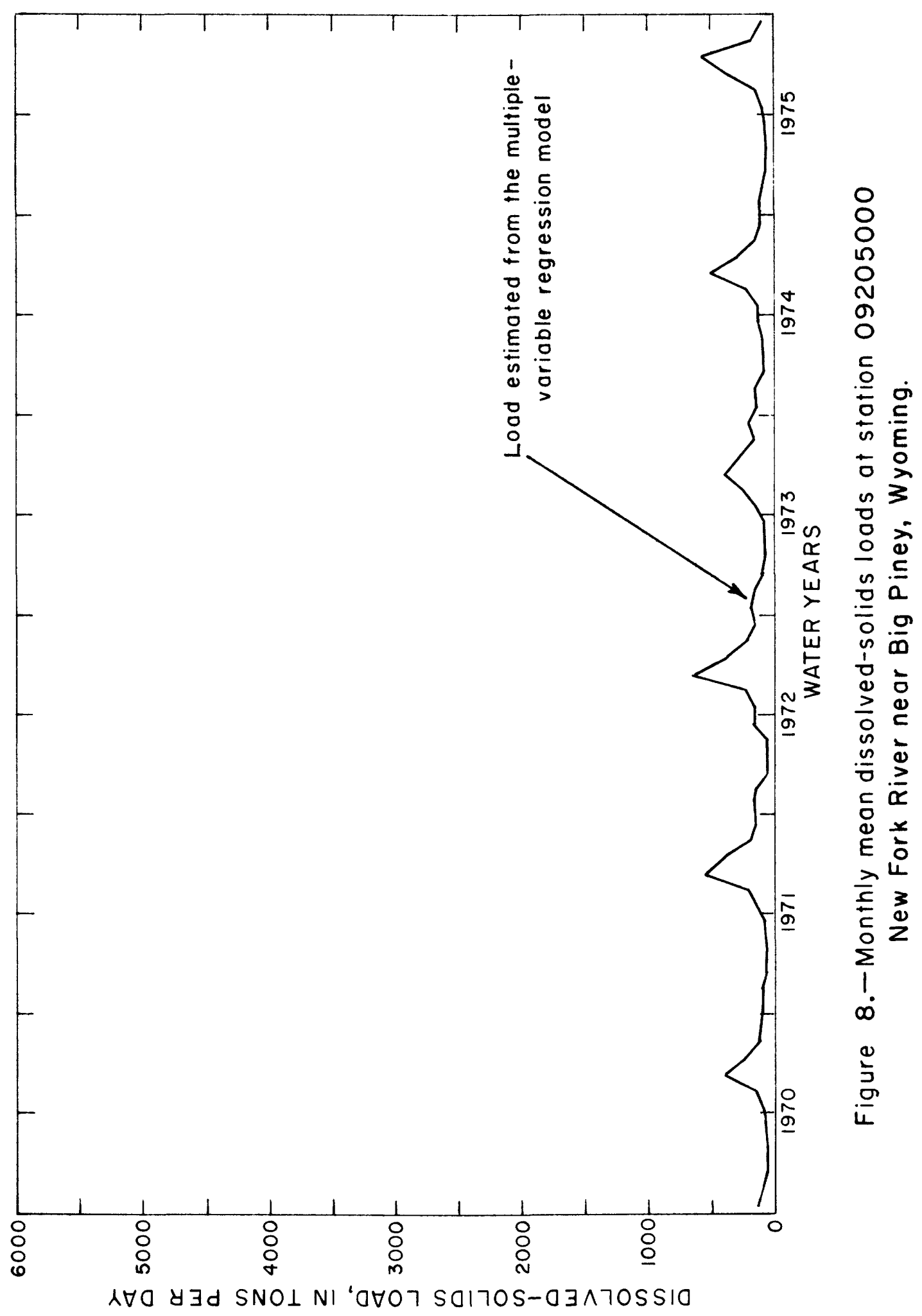




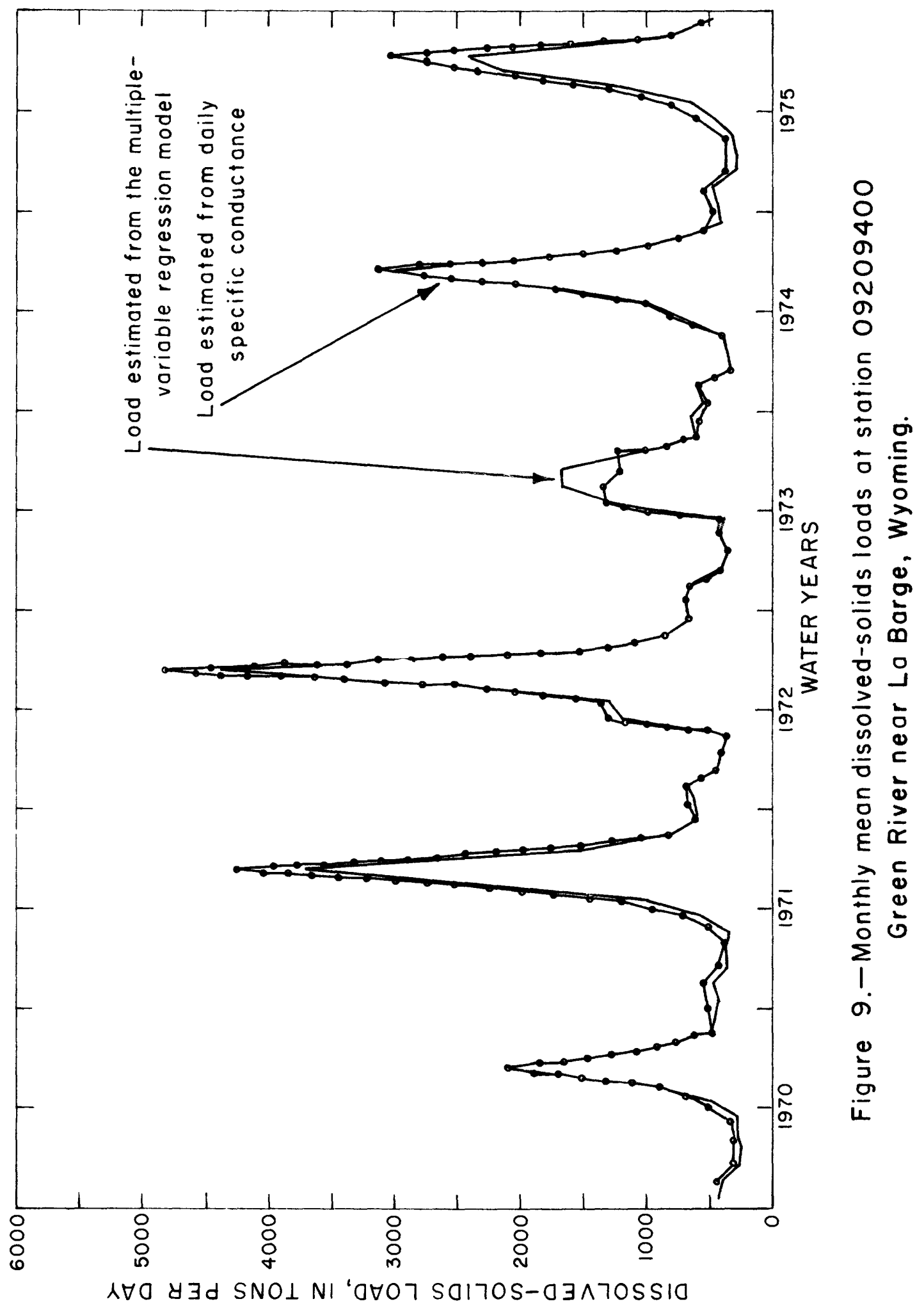




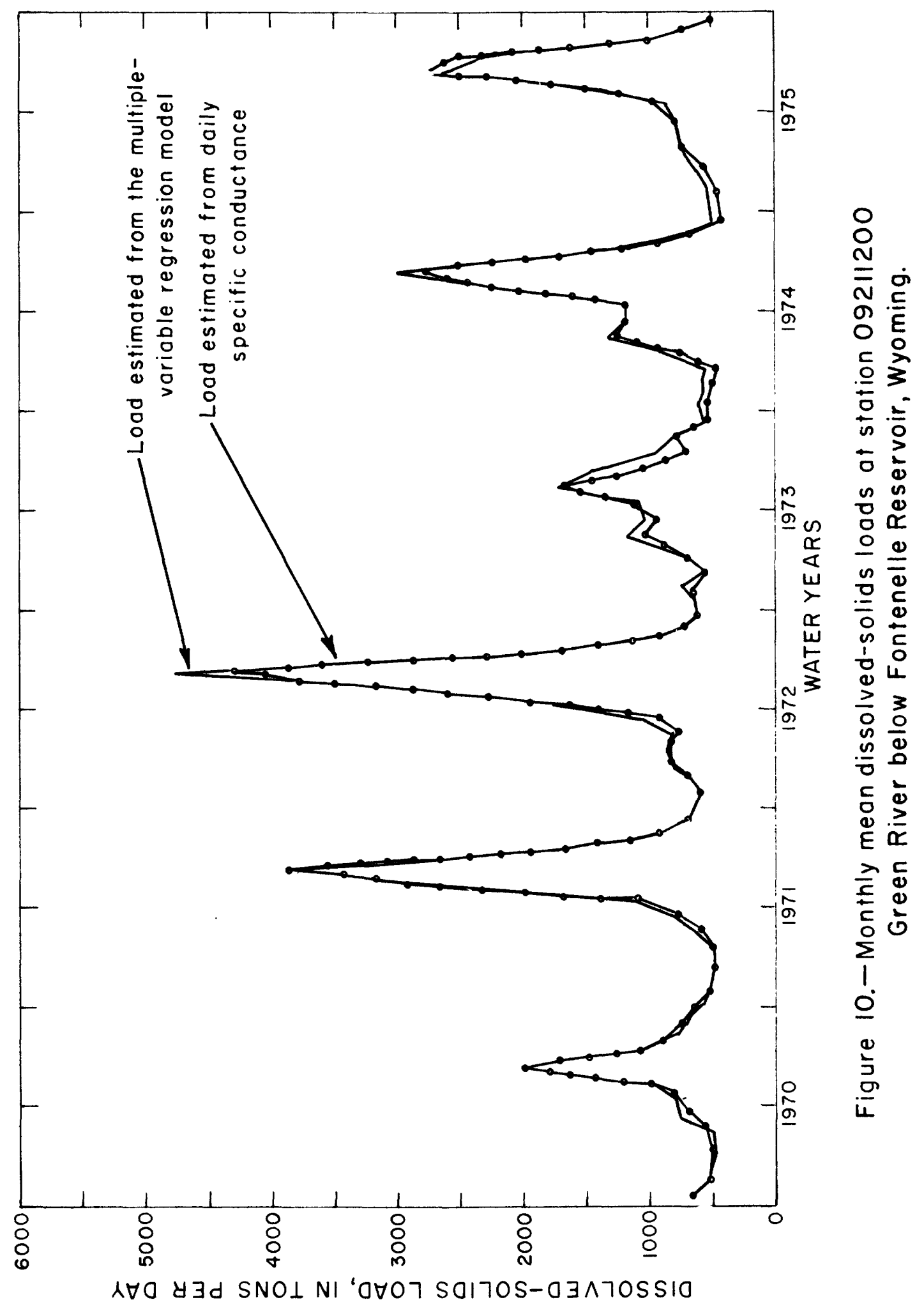




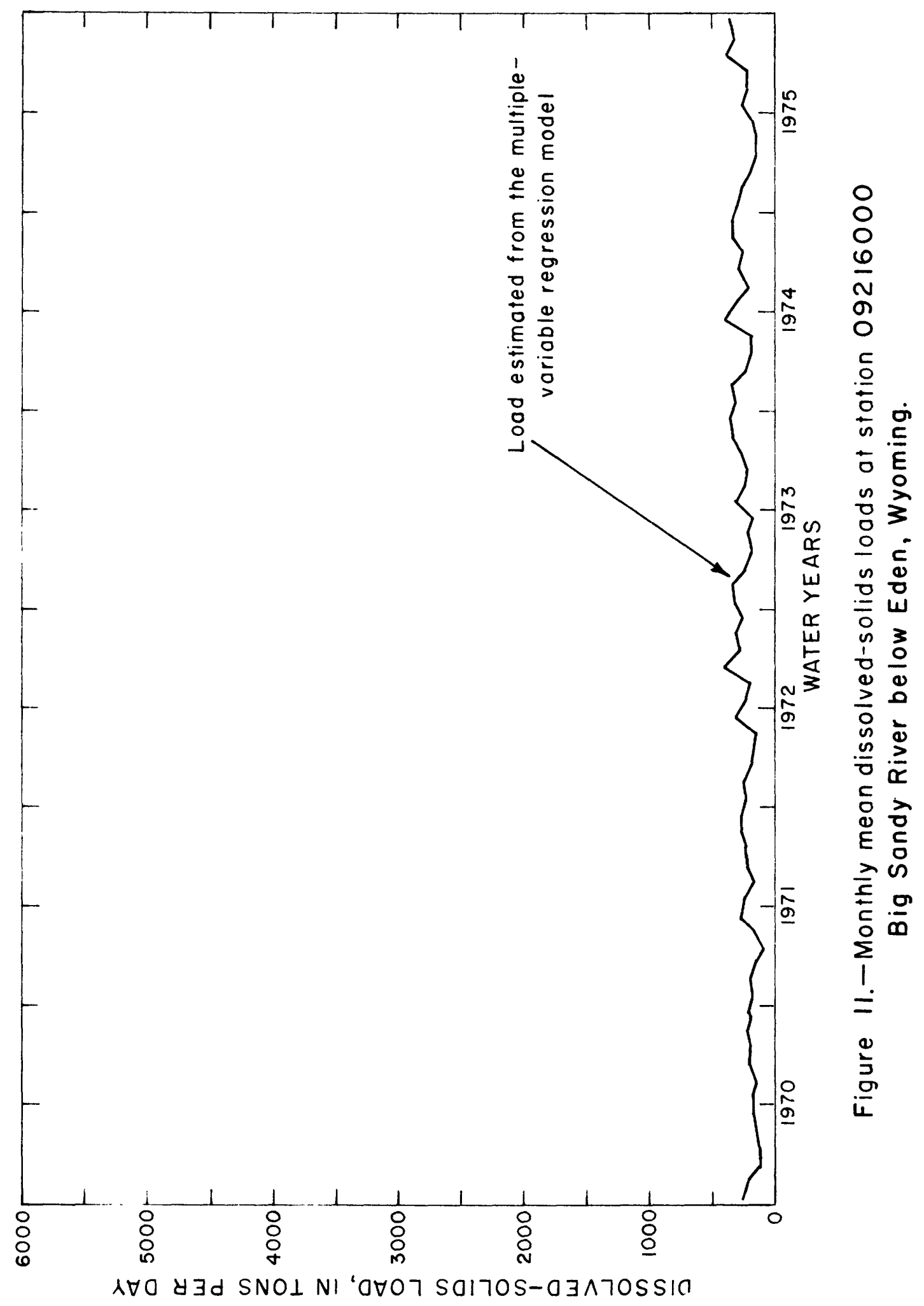




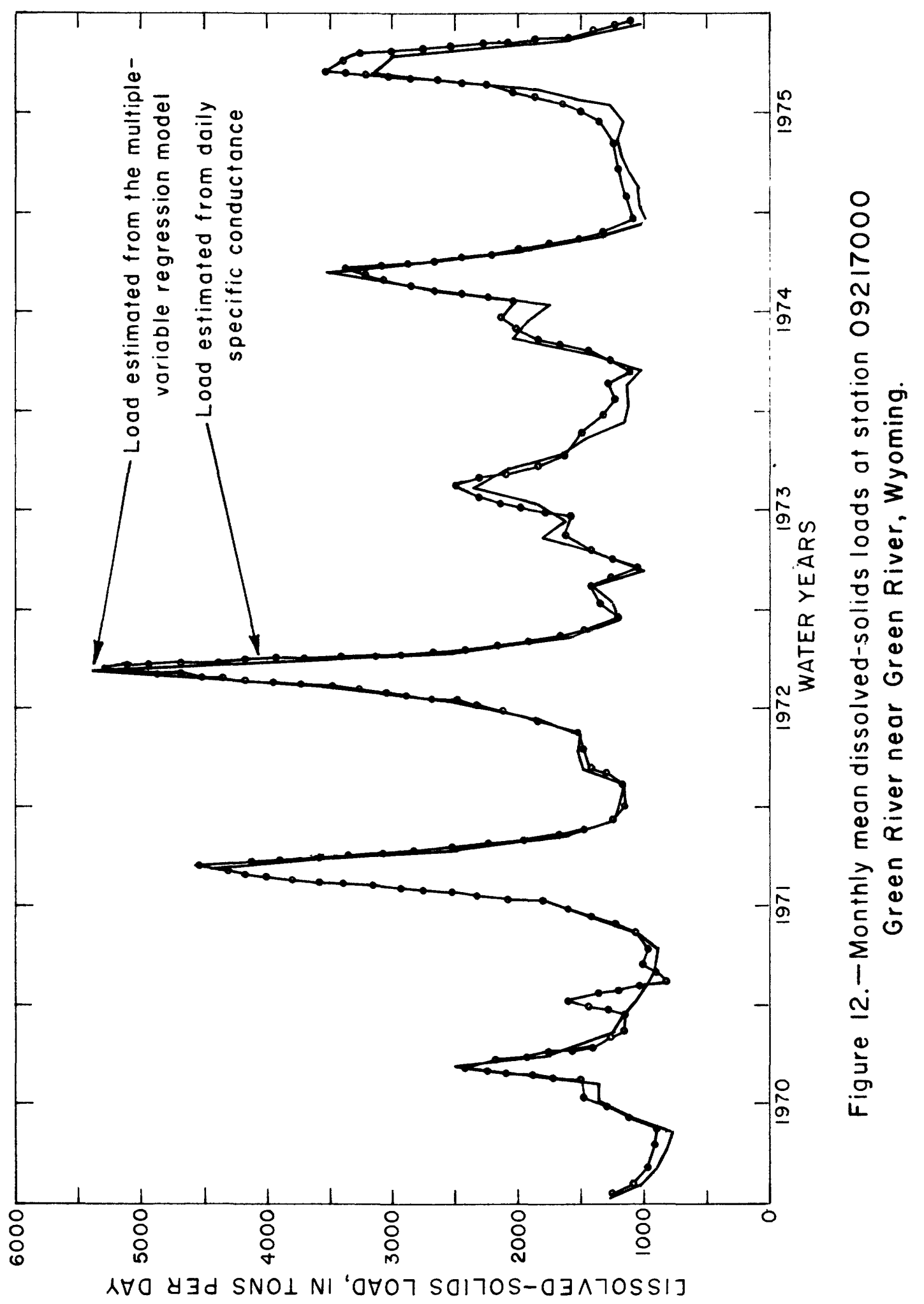




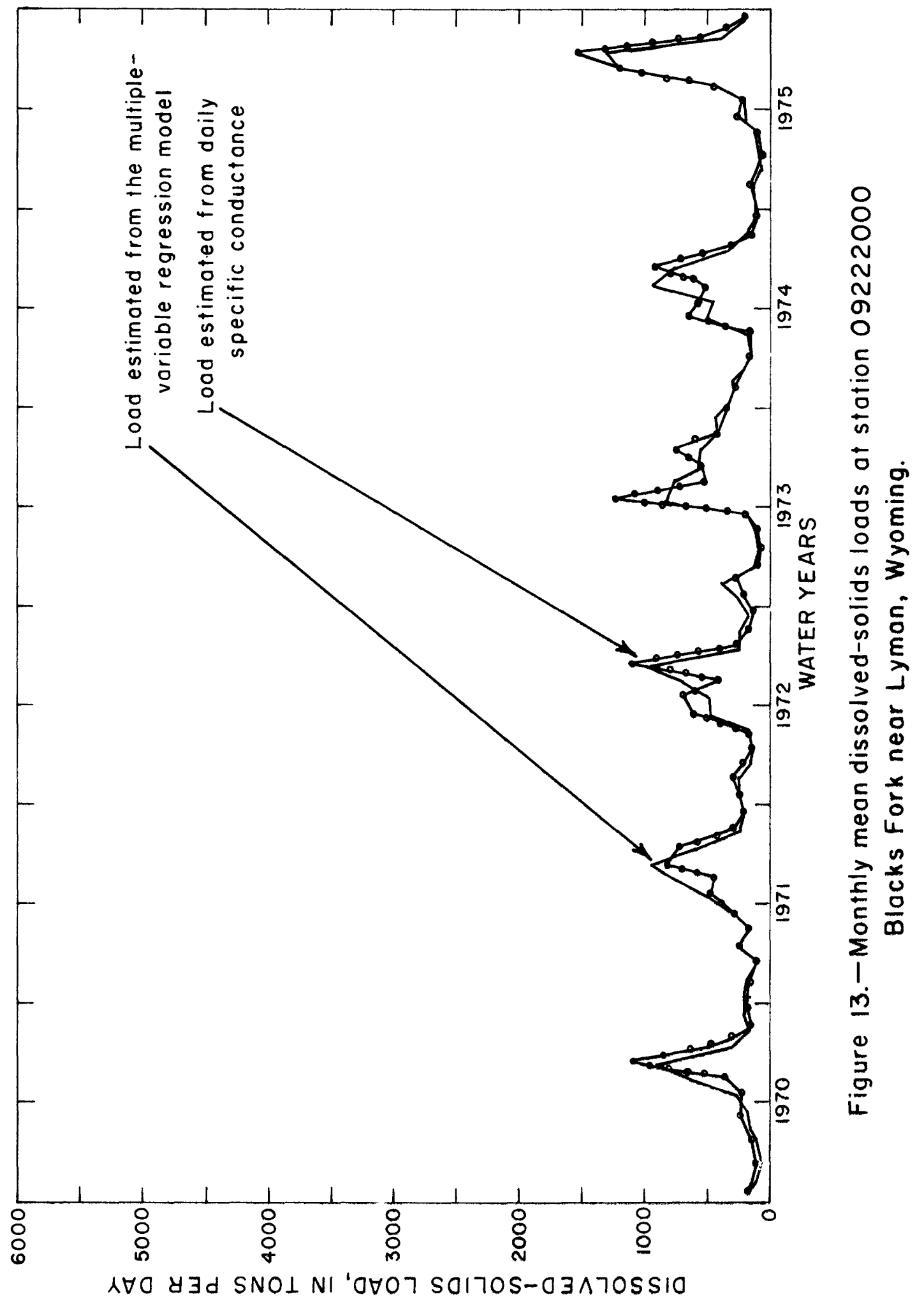




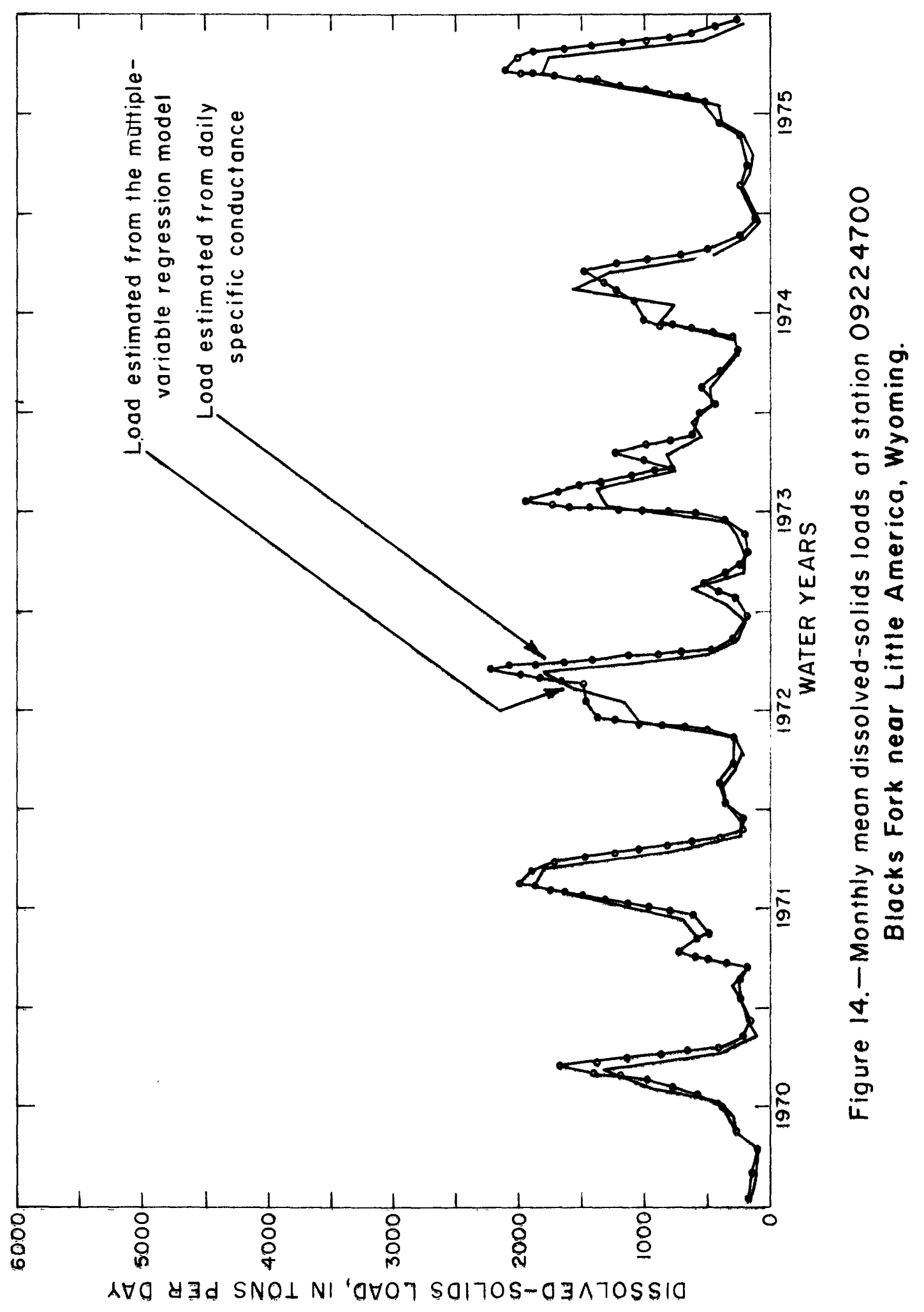


load hydrographs, comparison between stations of load magnitude and distribution with time can be made by visual inspection. For example, the base-flow loads at station 09211200 ( $\mathrm{fig}$. 10) increase in comparison to station 09209400 ( $\mathrm{fig}$. 9) without a corresponding increase in peakflow loads. In contrast, comparisons between stations 09217000 (fig. 12) and 09211200 ( $\mathrm{fig} .10$ ) indicate an increase of about 500 tons per day for both base-flow loads and peak-flow loads. While visual inspection of the example hydrographs aids in the evaluation of solute flow through a stream system, a more quantitative approach, as demonstrated in the following section, of ten is desirable.

\section{Delineation of Sources of Salinity}

Loads estimated at several points in a stream system collectively can provide quantitative information about the amount and chemical composition of dissolved solids gained in the intervening reaches.

For example, simulated dissolved-solids loads at stations 09211200 Green River below Fontenelle Reservoir and 09217000 Green River near Green River, Wyoming, show an average gain over the 1970-75 water years in the intervening reach of about 202,000 tons of dissolved solids per year. This gain represents about 33 percent of the load at station 09217000 and less than 5 percent of the streamflow. Big Sandy River is the major tributary to the Green River between stations 09211200 and 09217000. Simulated dissolved-solids loads averaged over the 1970-75 water years at station 09216000 Big Sandy River below Eden, Wyoming, 30 river miles upstream from the mouth, is 88,200 tons per year. The remaining increase of 114,000 tons per year is gained along the lower 30-mile reach of the Big Sandy River to the mouth and along the Green River between Fontenelle Reservoir and Green River, Wyoming. Cumulative dissolved-solids loads at stations 09211200, 09216000, and 09217000 are shown in figure 15 to illustrate the relative contribution of dissolved solids in the reaches between the stations.

More can be learned about the mean annual 114,000 ton-per-year dissolved-solids load by considering individual components of the load. Dissolved-sodium and dissolved-sulfate loads, plotted in figures 16 and 17, more than double in the Green River from below Fontenelle Reservoir to Green River, Wyoming. The average chemical composition of the 114,000 ton-per-year load is 84 percent sodium plus sulfate by weight compared to 31 and 72 percent sodium plus sulfate by weight in the loads at stations 09211200 and 09216000 . 


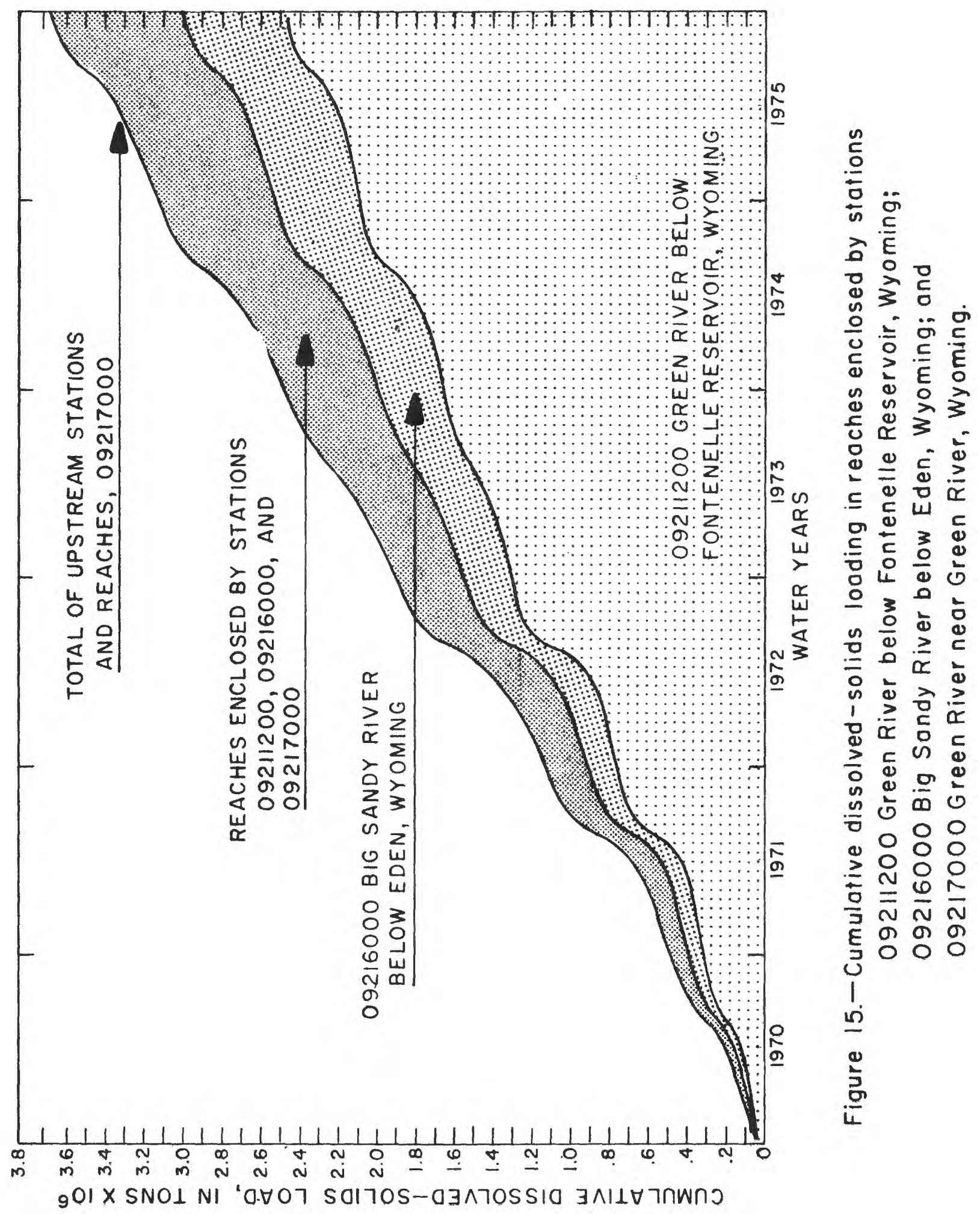




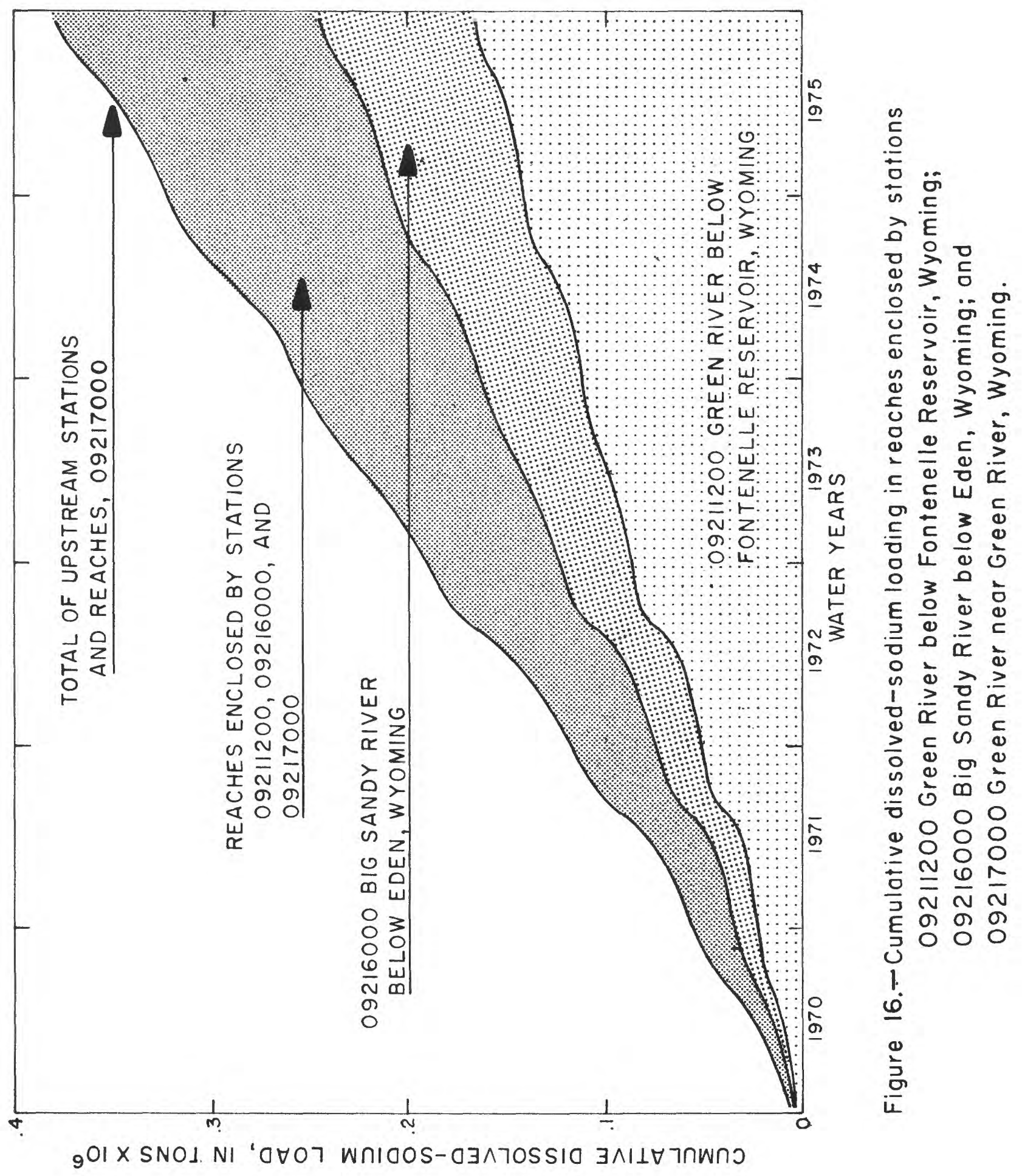




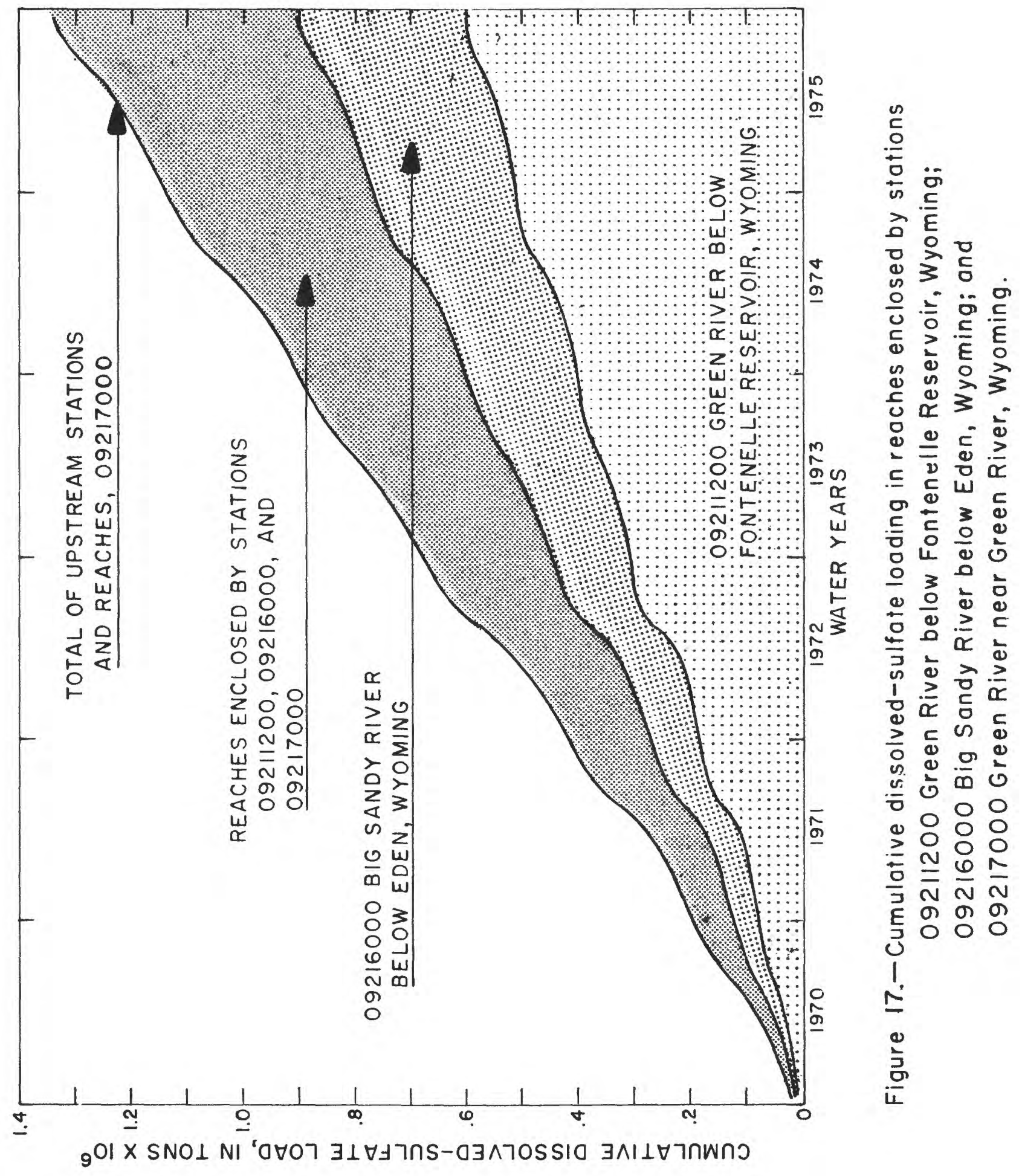


The chemical character of the dissolved-solids gain serves as an indicator of sources. Samples from seeps along the Big Sandy River downstream from station 09216000 range from 3,800 to 6,800 milligrams per liter dissolved solids of which 84 percent is sodium plus sulfate by weight. Station 09216050 Big Sandy River at Gasson Bridge near Eden, Wyoming, (fig. 2) was established downstream from the seeps in May 1972 for the purpose of collecting streamflow records. Because water-quality sampling at the station was not initiated until February 1975, there are not yet enough data available to estimate dissolved-solids loads to quantitatively determine the dissolved-solids contribution of seeps along the Big Sandy River between stations 09216000 and 09216050. Discharge from the seeps has not been measured directly, but streamflow records at the two stations indicate a mean discharge gain of about 20 cubic feet per second in October when there is less evapotranspiration and negligible surface-water gain. Based on an average flow from the seeps of 20 cubic feet per second at a concentration of 5,000 milligrams per liter dissolved solids, the annual discharge from the seeps would average about 100,000 tons of dissolved solids which would account for about 88 percent of the load gained in the Green River and Big Sandy reaches enclosed by stations 09211200 and 09216000 upstream, and 09217000 downstream. To demonstrate how the amount and chemical character collectively aid in delineating sources of salinity, the sum of sodium and sulfate loads versus total dissolved-solids load is plotted for this example in figure 18 . The close proximity of points representing the sum of the estimated seepage load and upstream stations to points representing loads at station 09217000 indicates good agreement both in amount and chemical character of the load gained in the intervening reaches despite a relatively large variation in loads at stations 09211200 and 09216000. Analyses similar to this example can be used in many other reaches where discrete monthly samples and daily streamflow records are available. This type of analysis would be difficult based on discrete monthly samples alone. 


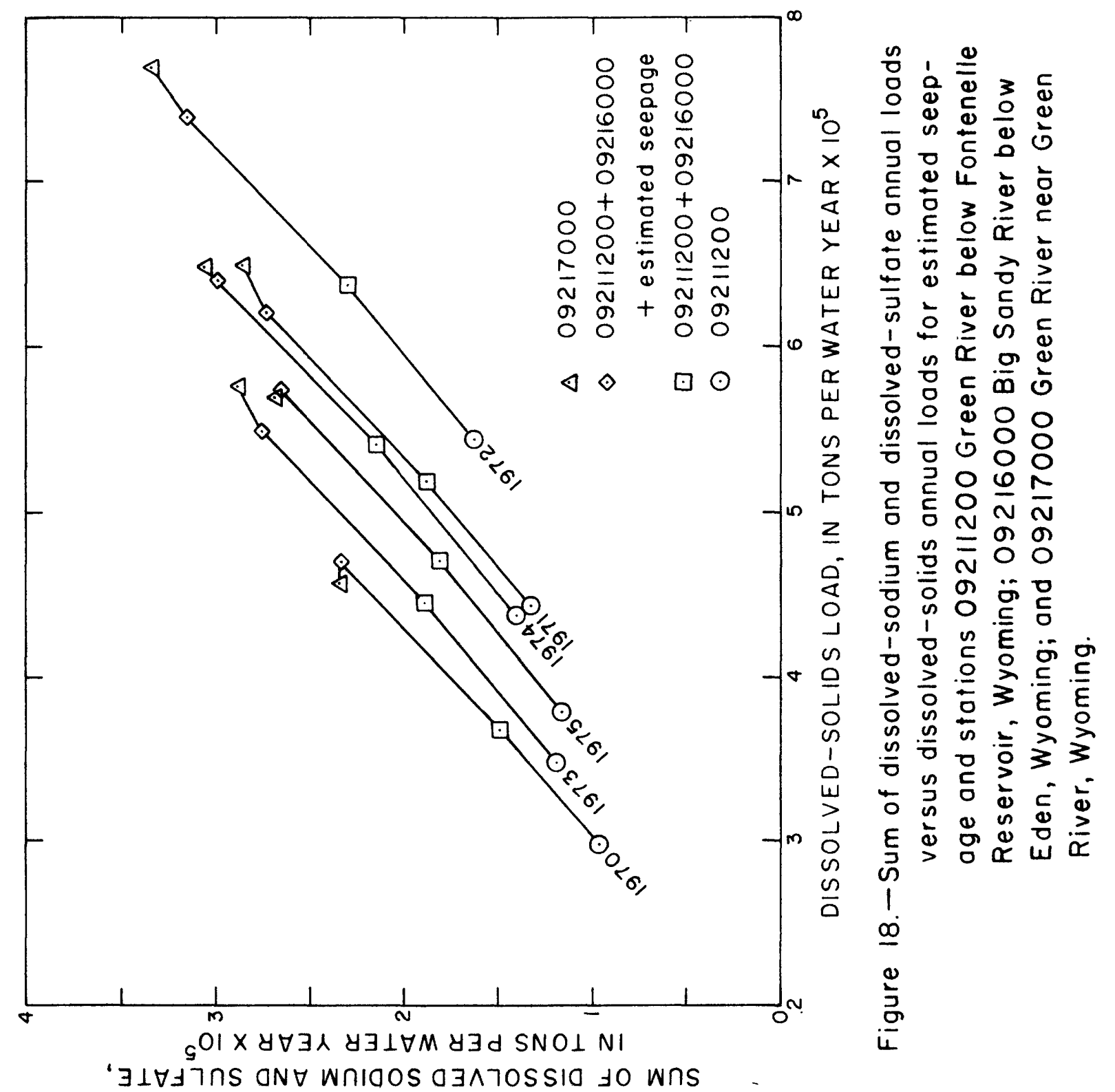


Daily concentration of dissolved solids in a stream may be estimated from daily streamflow records using a multiple-variable regression model developed from chemical analyses of samples collected on a monthly basis. The model relates dissolved-solids concentration of the stream to streamflow. Seasonal variation of dissolved solids not directly related to streamflow are accounted for in the model by the incorporation of harmonic functions of time. Because of the variability in streamflow and dissolvedsolids concentration of streams in the Green River Basin, monthly mean loads and concentrations computed from daily estimates from the model provide a better representation of overall dissolved-solids concentration of the streams than do discrete monthly samples. Consequently, estimates from the model of dissolved-solids concentrations provide information useful to water planners and managers concerned with the evaluation of impacts of proposed and past water-development projects (such as reservoirs irrigation systems, and withdrawals for municipal and industrial use). The model may also be utilized in assessing the feasibility of reduced sampling frequencies for providing continuing information on long-term trends in salinity-streamflow relations and shifts in sampling locations for providing additional information on sources of salinity. An overall reduction in the data collection effort allocated to salinity in the streams of the Green River Basin would allow greater emphasis to be applied to other equally important water-quality factors for which few data are presently available. 
Gunnerson, C. G., 1967, Streamflow and quality in the Columbia River Basin: Am. Soc. Civil Engineers Proc., Jour. Sanitary Eng. Div., December 1967,16 p.

Hem, J. D., 1970, Study and interpretation of the chemical characteristics of natural water: U.S. Geol. Survey Water-Supply Paper 1473, $363 \mathrm{p}$.

Lowham, H. W., De Long, L. L., Peter, K. D., Wangsness, D. J., Head, W. J., Ringen, B. K., 1976, A plan for study of water and its relation to economic development in the Green River and Great Divide basins in Wyoming: U.S. Geol. Survey Open-File Rept. 76-349, 92 p.

Steele, T. D., 1973, Computer simulation of solute concentrations and loads in streams: Internat. Assoc. for Hydraulic Research, Internat. Symposium on River Mechanics, Bangkok, Thailand, January 1973, p. C33-1-18.

1976, A bivariate-regression model for estimating chemical composition of streamflow or groundwater: Hydrologic Sciences, Bu11. v. 1, no. 21, March 1976, p. 149-161.

Steele, T. D., Gilroy, E. J., and Hawkinson, R. 0., 1974, An assessment of areal and temporal variations in streamflow quality using selected data from the National Stream Quality Accounting Network: U.S. Geol. Survey Open-File Rept. 74-217, 210 p. 
Table 2.--Sequence number conversion, date to water-year day

\begin{tabular}{|c|c|c|c|c|c|c|c|c|c|c|c|c|}
\hline Day & Oct & Nov & Dec & Jan & Feb & Mar & Apr & May & June & July & Aug & Sept \\
\hline 1 & 1 & 32 & 62 & 93 & 124 & 152 & 183 & 213 & 244 & 274 & 305 & 336 \\
\hline 2 & 2 & 33 & 63 & 94 & 125 & 153 & 184 & 214 & 245 & 275 & 306 & 337 \\
\hline 3 & 3 & 34 & 64 & 95 & 126 & 154 & 185 & 215 & 246 & 276 & 307 & 338 \\
\hline 4 & 4 & 35 & 65 & 96 & 127 & 155 & 186 & 216 & 247 & 277 & 308 & 339 \\
\hline 5 & 5 & 36 & 66 & 97 & 128 & 156 & 187 & 217 & 248 & 278 & 309 & 340 \\
\hline 6 & 6 & 37 & 67 & 98 & 128 & 157 & 188 & 218 & 249 & 279 & 310 & 341 \\
\hline 7 & 7 & 38 & 68 & 99 & 130 & 158 & 189 & 219 & 250 & 280 & 311 & 342 \\
\hline 8 & 8 & 39 & 69 & 100 & 131 & 159 & 190 & 220 & 251 & 281 & 312 & 343 \\
\hline 9 & 9 & 40 & 70 & 101 & 132 & 160 & 191 & 221 & 252 & 282 & 313 & 344 \\
\hline 10 & 10 & 41 & 71 & 102 & 133 & 161 & 192 & 222 & 253 & 283 & 314 & 345 \\
\hline 11 & 11 & 42 & 72 & 103 & 134 & 162 & 193 & 223 & 254 & 284 & 315 & 346 \\
\hline 12 & 12 & 43 & 73 & 104 & 135 & 163 & 194 & 224 & 255 & 285 & 316 & 347 \\
\hline 13 & 13 & 44 & 74 & 105 & 136 & 164 & 195 & 225 & 256 & 286 & 317 & 348 \\
\hline 14 & 14 & 45 & 75 & 106 & 137 & 165 & 196 & 226 & 257 & 287 & 318 & 349 \\
\hline 15 & 15 & 46 & 76 & 107 & 138 & 166 & 197 & 227 & 258 & 288 & 319 & 350 \\
\hline 16 & 16 & 47 & 77 & 108 & 139 & 167 & 198 & 228 & 259 & 289 & 320 & 351 \\
\hline 17 & 17 & 48 & 78 & 109 & 140 & 168 & 199 & 229 & 260 & 290 & 321 & 352 \\
\hline 18 & 18 & 49 & 79 & 110 & 141 & 169 & 200 & 230 & 261 & 291 & 322 & 353 \\
\hline 19 & 19 & 50 & 80 & 111 & 142 & 170 & 201 & 231 & 262 & 292 & 323 & 354 \\
\hline 20 & 20 & 51 & 81 & 112 & 143 & 171 & 202 & 232 & 263 & 293 & 324 & 355 \\
\hline 21 & 21 & 52 & 82 & 113 & 144 & 172 & 203 & 233 & 264 & 294 & 325 & 356 \\
\hline 22 & 22 & 53 & 83 & 114 & 145 & 173 & 204 & 234 & 265 & 295 & 326 & 357 \\
\hline 23 & 23 & 54 & 84 & 115 & 146 & 174 & 205 & 235 & 266 & 296 & 327 & 358 \\
\hline 24 & 24 & 55 & 85 & 116 & 147 & 175 & 206 & 236 & 267 & 297 & 328 & 359 \\
\hline 25 & 25 & 56 & 86 & 117 & 148 & 176 & 207 & 237 & 268 & 298 & 329 & 360 \\
\hline 26 & 26 & 57 & 87 & 118 & 149 & 177 & 208 & 238 & 269 & 299 & 330 & 361 \\
\hline 27 & 27 & 58 & 88 & 119 & 150 & 178 & 209 & 239 & 270 & 300 & 331 & 362 \\
\hline 28 & 28 & 59 & 89 & 120 & 151 & 179 & 210 & 240 & 271 & 301 & 332 & 363 \\
\hline 29 & 29 & 60 & 90 & 121 & (152) & 180 & 211 & 241 & 272 & 302 & 333 & 364 \\
\hline 30 & 30 & 61 & 91 & 122 & $-\infty$ & 181 & 212 & 242 & 273 & 303 & 334 & 365 \\
\hline 31 & 31 & $-m$ & 92 & 123 & -- & 182 & -- & 243 & -- & 304 & 335 & $=-$ \\
\hline
\end{tabular}

Note: For months of March through September add one (1) to number in table for sequence conversion of days for leap years. 
Table 3.--Regression results, concentration versus discharge and time

where

$$
C=10 B_{Q}^{\left[B_{0}+B_{1} \sin (\alpha t)+B_{2} \cos (\alpha t)\right]}\left[B_{3}+B_{4} \sin (\alpha t)+B_{5} \cos (\alpha t)\right]
$$

$C=$ Constituent concentration, in milligrams per Liter.

$\mathrm{Q}=$ Discharge, in cubic feet per second.

$\mathrm{B}_{0}$ through $\mathrm{B}_{5}=$ Regression coefficients.

$\alpha=0.987$ degrees per day or 0.0172 radians per day.

$t=$ Day of water year. $r=$ Correlation coefficient.

$\mathrm{SE}=$ Standard error of estimate, log units.

$\mathrm{N}=$ Number of samples.

$\begin{array}{rrr}\text { Constituents (concentrations are in milligrams per liter): } \\ \mathrm{Ca}=\text { calcium } & \mathrm{HCO}_{3}=\text { bicarbonate } \\ \mathrm{Mg}=\text { magnesium } & \mathrm{SO}_{4}=\text { sulfate } \\ \mathrm{Na}=\text { sodium } & \mathrm{CL}=\text { chloride } \\ \mathrm{K}=\text { potasium } & \mathrm{TDS}=\text { dissolved solids }\end{array}$

\begin{tabular}{lllllllll}
\hline $\begin{array}{l}\text { Con- } \\
\text { stitu- } \\
\text { ent }\end{array}$ & $B_{0}$ & $B_{1}$ & $B_{2}$ & $B_{3}$ & $B_{4}$ & $B_{5}$ & SE & $($ Iog \\
units)
\end{tabular}

09188500 Green River at Warren Bridge, near Daniel, Wyo., 1968-75 water years

\begin{tabular}{lrrrrrrrrr}
\hline $\mathrm{Ca}$ & 2.4454 & -0.3368 & 0.5140 & -0.2555 & 0.1819 & -0.2513 & 0.981 & 0.045 & 78 \\
$\mathrm{Mg}$ & 1.8932 & -.3916 & .6109 & -.3043 & .2072 & -.3014 & .949 & .086 & 78 \\
$\mathrm{Na}$ & .8680 & -.4383 & .5463 & -.1274 & .2191 & -.2654 & .829 & .116 & 78 \\
$\mathrm{~K}$ & .0586 & -.4819 & .2751 & $.9698 \times 10^{-2}$ & .2265 & -.1690 & .695 & .128 & 78 \\
$\mathrm{HCO}_{3}$ & 2.4140 & -.2260 & .6311 & -.1248 & .1293 & -.3068 & .965 & .044 & 78 \\
$\mathrm{SO}_{4}$ & 3.0835 & -.5370 & .3708 & -.4159 & .2739 & -.1863 & .986 & .055 & 77 \\
$\mathrm{Cl}$ & .3870 & -.3415 & .6011 & $-.8663 \times 10^{-1}$ & .1641 & -.2640 & .415 & .250 & 77 \\
$\mathrm{TDS}$ & 3.0855 & -.3275 & .4789 & -.2617 & .1814 & -.2407 & .985 & .041 & 78
\end{tabular}

09192600 Green River near Big Piney, Wyo., 1967-75 water years

\begin{tabular}{|c|c|c|c|c|c|c|c|c|c|}
\hline $\mathrm{Ca}$ & 1.7843 & $0.9890 \times 10^{-1}$ & $0.9982 \times 10^{-1}$ & $-0.3792 \times 10^{-2}$ & $0.2161 \times 10^{-1}$ & $-0.5733 \times 10^{-1}$ & 0.910 & 0.056 & 89 \\
\hline $\mathrm{Mg}$ & 1.0344 & $-.7263 \times 10^{-1}$ & $.5276 \times 10^{-1}$ & $.5451 \times 10^{-1}$ & $.9910 \times 10^{-1}$ & $-.5017 \times 10^{-1}$ & .825 & .095 & 89 \\
\hline $\mathrm{Na}$ & .4995 & -.9178 & .3005 & .1697 & .3824 & -.1512 & .569 & .164 & 89 \\
\hline $\mathrm{K}$ & .2784 & -.3790 & .3183 & .1800 & .1863 & -.1610 & .712 & .102 & 89 \\
\hline $\mathrm{HCO}_{3}$ & 1.9968 & $.9484 \times 10^{-1}$ & .1246 & $.8842 \times 10^{-1}$ & $.1397 \times 10^{-1}$ & $-.7213 \times 10^{-1}$ & .852 & .053 & 89 \\
\hline $\mathrm{SO}_{4}$ & 2.2344 & -.4376 & $.4258 \times 10^{-1}$ & -.1120 & .2469 & $-.4056 \times 10^{-1}$ & .945 & .080 & 89 \\
\hline $\mathrm{Cl}$ & .9049 & -.2238 & .6090 & -.1906 & $.7529 \times 10^{-1}$ & $=.2718$ & .314 & .339 & 85 \\
\hline TDS & 2.4224 & $-.7516 \times 10^{-1}$ & .1077 & $.5206 \times 10^{-2}$ & $.8699 \times 10^{-1}$ & $-.6815 \times 10^{-1}$ & .927 & .052 & 89 \\
\hline
\end{tabular}

09205000 New Fork River near Big Piney, Wyo., 1969-75 water year

\begin{tabular}{lrrllrrrrr}
\hline $\mathrm{Ca}$ & 2.1925 & -0.4160 & -0.4160 & -0.2947 & 0.1498 & 0.1200 & 0.893 & 0.078 & 71 \\
$\mathrm{Mg}$ & .7144 & -.5475 & -.5633 & $-.1464 \times 10^{-1}$ & .2410 & .2187 & .564 & .186 & 70 \\
$\mathrm{Na}$ & 1.4866 & -.8208 & -.2626 & -.1899 & .3111 & .1078 & .858 & .098 & 71 \\
$\mathrm{~K}$ & .3708 & -.6029 & $-.8019 \times 10^{-1}$ & $-.44406 \times 10^{-1}$ & .2294 & $.2738 \times 10^{-1}$ & .567 & .120 & 70 \\
$\mathrm{HCO}_{3}$ & 2.7188 & -.4023 & -.5371 & -.2641 & .1458 & .2191 & .879 & .083 & 71 \\
$\mathrm{SO}_{4}$ & 1.5564 & -.7377 &. .3968 & -.1672 & .2992 & -.1518 & .631 & .196 & 70 \\
$\mathrm{Cl}$ & .7356 & -.7806 & .3370 & $-.8435 \times 10^{-1}$ & .3120 & -.1411 & .532 & .200 & 68 \\
$\mathrm{TDS}$ & 2.6440 & -.4413 & -.2889 & -.2109 & .1687 & .1254 & .851 & .087 & 70 \\
\hline
\end{tabular}

09209400 Green River near La Barge, Wyo., 1970-75 water years

\begin{tabular}{|c|c|c|c|c|c|c|c|c|c|}
\hline $\mathrm{Ca}$ & 1.9262 & -0.1408 & 0.4260 & $-0.8631 \times 10^{-1}$ & $0.6860 \times 10^{-1}$ & -0.1532 & 0.857 & 0.051 & 59 \\
\hline $\mathrm{Mg}$ & 1.4935 & -.1518 & .1662 & -.1294 & $.6249 \times 10^{-1}$ & $-.7216 \times 10^{-1}$ & .644 & .100 & 59 \\
\hline $\mathrm{Na}$ & 1.3806 & -1.150 & .6504 & $-.6527 \times 10^{-1}$ & .4034 & -.2239 & .786 & .107 & 59 \\
\hline $\mathrm{K}$ & .1218 & -.6747 & .7754 & $.4045 \times 10^{-1}$ & .2318 & -.2802 & .613 & .104 & 59 \\
\hline $\mathrm{HCO}$ & 2.5069 & -.1116 & .3261 & $-.9231 \times 10^{-1}$ & $.4692 \times 10^{-1}$ & -.1192 & .784 & .049 & 58 \\
\hline so & 2.2587 & -.7708 & .4432 & -.1699 & .2946 & -.1665 & .926 & .075 & 58 \\
\hline C1 & .2396 & -1.028 & .3341 & .1219 & .3955 & -.1445 & .620 & .187 & 59 \\
\hline TDS & 2.5593 & -.4033 & .3956 & $-.6532 \times 10^{-1}$ & .1555 & -.1459 & .864 & .053 & 59 \\
\hline
\end{tabular}

09211200 Green River below Fontene1le Reservoir, Wyo., 1970-75 water years

\begin{tabular}{|c|c|c|c|c|c|c|c|c|c|}
\hline $\mathrm{Ca}$ & 1.8813 & $-0.7463 \times 10^{-1}$ & 0.1242 & $-0.6576 \times 10^{-1}$ & $0.3601 \times 10^{-1}$ & $-0.6532 \times 10^{-1}$ & 0.858 & 0.044 & 59 \\
\hline $\mathrm{Mg}$ & 2.1434 & .3819 & $-.9552 \times 10^{-1}$ & -.3400 & -.1351 & $-.8903 \times 10^{-3}$ & .582 & .118 & 59 \\
\hline $\mathrm{Na}$ & 2.1664 & $-.7561 \times 10^{-1}$ & .5277 & .2969 & $.3505 \times 10^{-1}$ & -.1969 & .838 & .079 & 59 \\
\hline $\mathrm{K}$ & .2186 & .1826 & -.2944 & $-.7194 \times 10^{-2}$ & $-.6705 \times 10^{-2}$ & $.7906 \times 10^{-1}$ & .494 & .081 & 59 \\
\hline $\mathrm{HCO}_{3}$ & 2,3076 & $.1433 \times 10^{-2}$ & $-.7979 \times 10^{-1}$ & $-.3280 \times 10^{-1}$ & $.4625 \times 10^{-2}$ & $.5705 \times 10^{-2}$ & .785 & .039 & 59 \\
\hline $\mathrm{SO}_{4}$ & 2.8633 & -.2999 & .8828 & -.3392 & .1028 & -.3247 & .897 & .074 & 56 \\
\hline $\mathrm{Cl}$ & 1.1211 & $.9124 \times 10^{-1}$ & -.4148 & -.1548 & $-.9964 \times 10^{-2}$ & $.7716 \times 10^{-1}$ & .660 & .172 & 58 \\
\hline TDS & 2.9542 & $.4108 \times 10^{-1}$ & .2386 & -.1848 & $-.8943 \times 10^{-2}$ & -.1036 & .904 & .038 & 59 \\
\hline
\end{tabular}




\begin{tabular}{|c|c|c|c|c|c|c|c|c|c|c|}
\hline \multirow[t]{2}{*}{$\begin{array}{l}\text { Con- } \\
\text { stitu- } \\
\text { ent }\end{array}$} & $\mathrm{B}_{\mathrm{O}}$ & $\mathrm{B}_{1}$ & & $\mathrm{~B}_{2}$ & $\mathrm{~B}_{3}$ & $\mathrm{~B}_{4}$ & $\mathrm{~B}_{5}$ & $\mathbf{r}$ & $\begin{array}{l}\mathrm{SE} \\
\text { (log } \\
\text { units) }\end{array}$ & $\mathrm{N}$ \\
\hline & 09216 & Big & Sandy & River below & Eden, Wyo., & 1961-75 water & years & & & \\
\hline $\mathrm{Ca}$ & 2.8308 & -0.2819 & & -0.3118 & -0.3193 & 0.2238 & 0.2298 & 0.930 & 0.065 & 135 \\
\hline $\mathrm{Mg}$ & 2.5163 & -.4769 & & -.4435 & -.3962 & .3409 & .2906 & .763 & .170 & 133 \\
\hline $\mathrm{Na}$ & 3.1705 & -.5360 & & -.1425 & -.4107 & .3546 & $.9222 \times 10^{-1}$ & .921 & .075 & 136 \\
\hline $\mathrm{K}$ & .8432 & -.2324 & & -.1871 & -.1831 & .1371 & .1271 & .747 & .070 & 134 \\
\hline $\mathrm{HCO}_{3}$ & 2.6226 & -.2080 & & -.2263 & -.1526 & .1509 & .1526 & .856 & .052 & 136 \\
\hline $\mathrm{SO}_{4}$ & 3.7132 & -.4768 & & -.3024 & -.3867 & .3453 & .2078 & .939 & .071 & 132 \\
\hline $\mathrm{Cl}^{4}$ & 2.6059 & -.6753 & & $-.5450 \times 10^{-1}$ & -.5222 & .3899 & $.5756 \times 10^{-1}$ & .911 & .090 & 134 \\
\hline TDS & 3.9191 & -.4373 & & -.2577 & -.3697 & .3102 & .1791 & .938 & .065 & 134 \\
\hline
\end{tabular}

09216300 Green River at Big Island, near Green River, Wyo., 1966-75 water years

\begin{tabular}{|c|c|c|c|c|c|c|c|c|c|}
\hline $\mathrm{Ca}$ & 2.3985 & $0.9136 \times 10^{-1}$ & 0.1184 & -0.2114 & $-0.1983 \times 10^{-1}$ & $-0.5649 \times 10^{-1}$ & 0.906 & 0.042 & 102 \\
\hline $\mathrm{Mg}$ & 2.3717 & .1850 & .118 & -.3557 & $-.5387 \times 10^{-1}$ & $-.5183 \times 10^{-1}$ & .789 & .097 & 102 \\
\hline $\mathrm{Na}$ & 3.5144 & -.1151 & .4623 & -.6195 & $.3199 \times 10^{-1}$ & -.1610 & .900 & .094 & 102 \\
\hline $\mathrm{K}$ & .4599 & $.4617 \times 10^{-1}$ & .1556 & $-.7425 \times 10^{-1}$ & $.2488 \times 10^{-1}$ & $-.6086 \times 10^{-1}$ & .298 & .092 & 102 \\
\hline $\mathrm{HCO}_{3}$ & 2.4754 & .2112 & $.8044 \times 10^{-2}$ & $-.8492 \times 10^{-1}$ & $-.5954 \times 10^{-1}$ & $-.1613 \times 10^{-1}$ & .843 & .038 & 102 \\
\hline $\mathrm{SO}_{4}$ & 4.1100 & -.2129 & .3763 & -.6234 & $.7070 \times 10^{-1}$ & -.1364 & .921 & .088 & 101. \\
\hline $\mathrm{Cl}$ & 2.7664 & -.6385 & .6583 & -.6096 & .1907 & -.2426 & .804 & .141 & 101 \\
\hline TDS & 2.4358 & $.1564 \times 10^{-1}$ & $.5281 \times 10^{-1}$ & $-.6429 \times 10^{-1}$ & $.8525 \times 10^{-3}$ & $-.2016 \times 10^{-1}$ & .981 & .026 & 90 \\
\hline
\end{tabular}

09217000 Green River near Green River, Wyo., 1969-75 water years

\begin{tabular}{|c|c|c|c|c|c|c|c|c|c|}
\hline $\mathrm{Ca}$ & 2.3422 & $.7921 \times 10^{-1}$ & .3339 & -.3339 & $-.1773 \times 10^{-1}$ & -.1223 & .914 & .031 & 79 \\
\hline $\mathrm{Mg}$ & 2.0169 & $-.6733 \times 10^{-1}$ & $.5429 \times 10^{-1}$ & -.2299 & $.3125 \times 10^{-1}$ & $-.3226 \times 10^{-1}$ & .849 & .053 & 79 \\
\hline $\mathrm{Na}$ & 2.9491 & -.7523 & .1445 & -.4147 & .2477 & $-.5830 \times 10^{-1}$ & .833 & 105 & 79 \\
\hline $\mathrm{K}$ & .1949 & -.3300 & .1001 & $.2950 \times 10^{-1}$ & .1050 & $-.4980 \times 10^{-1}$ & .373 & .114 & 68 \\
\hline $\mathrm{HCO}_{3}$ & 2.4509 & .1540 & .1388 & $-.7179 \times 10^{-1}$ & $-.4039 \times 10^{-1}$ & $-.6137 \times 10^{-1}$ & .866 & .029 & 79 \\
\hline $\mathrm{SO}_{4}$ & 3.7297 & -.4682 & .4333 & -.4920 & .1560 & -.1485 & .934 & .065 & 68 \\
\hline $\mathrm{C} 1$ & 1.8550 & -.4853 & .3897 & -.3137 & .1587 & -.1463 & .802 & .089 & 68 \\
\hline TDS & 3.4821 & -.1001 & .3078 & -.2910 & $.4131 \times 10^{-1}$ & -.1087 & .935 & .039 & 68 \\
\hline
\end{tabular}

09222000 Blacks Fork near Lyman, Wyo., 1970-75 water years

\begin{tabular}{|c|c|c|c|c|c|c|c|c|c|}
\hline $\mathrm{Ca}$ & 2.6737 & -0.1666 & $0.2548 \times 10^{-1}$ & -0.3078 & $0.2669 \times 10^{-1}$ & $0.3359 \times 10^{-1}$ & 0.951 & 0.062 & 53 \\
\hline $\mathrm{Mg}$ & 2.2836 & -.3277 & $-.3364 \times 10^{-1}$ & -.3487 & .1007 & $.7367 \times 10^{-1}$ & .934 & .089 & 54 \\
\hline $\mathrm{Na}$ & 2.6877 & -.6437 & .3100 & -.2599 & .2574 & $-.9781 \times 10^{-1}$ & .884 & .126 & 53 \\
\hline $\mathrm{K}$ & .5752 & -.4374 & .2794 & $-.4799 \times 10^{-1}$ & .1716 & -.1409 & .775 & .082 & 54 \\
\hline $\mathrm{HCO}_{3}$ & 2.5942 & $-.9595 \times 10^{-3}$ & -.2064 & -.1076 & $-.1372 \times 10^{-1}$ & $.9670 \times 10^{-1}$ & .679 & .053 & 54 \\
\hline $\mathrm{SO}_{4}{ }^{3}$ & 3.3881 & -.4991 & .1929 & -.3596 & .1776 & $-.1158 \times 10^{-1}$ & .931 & .113 & 54 \\
\hline $\mathrm{Cl} 1^{4}$ & 1.9935 & -.7167 & .2139 & -.1367 & .3011 & $-.8693 \times 10^{-1}$ & .710 & .167 & 54 \\
\hline TDS & 3.5611 & -.4165 & .1823 & -.2872 & .1476 & $-.3277 \times 10^{-1}$ & .930 & .087 & 54 \\
\hline
\end{tabular}

09224450 Hams Fork near Granger, Wyo., 1969-75 water years

\begin{tabular}{|c|c|c|c|c|c|c|c|c|c|}
\hline $\mathrm{Ca}$ & 1.9122 & 0.1702 & -0.1251 & $-0.3613 \times 10^{-1}$ & $-0.6055 \times 10^{-1}$ & $0.5120 \times 10^{-1}$ & 0.771 & 0.069 & 88 \\
\hline Mg & 1.6777 & .1173 & -.1355 & -.1912 & $-.7256 \times 10^{-1}$ & $.6406 \times 10^{-1}$ & .815 & 0.084 & 88 \\
\hline $\mathrm{Na}$ & 1.9557 & $.1579 \times 10^{-1}$ & -.1859 & -.2271 & $-.5991 \times 10^{-2}$ & .1140 & .832 & .116 & 88 \\
\hline $\mathrm{K}$ & .2819 & $.9825 \times 10^{-1}$ & $.1170 \times 10^{-1}$ & $-.2305 \times 10^{-1}$ & $-.5176 \times 10^{-1}$ & $-.3552 \times 10^{-1}$ & .476 & .082 & 88 \\
\hline $\mathrm{HCO}_{3}$ & 2.4167 & .1674 & $-.9874 \times 10^{-1}$ & $-.5596 \times 10^{-1}$ & -.1046 & $.4351 \times 10^{-1}$ & .658 & .057 & 88 \\
\hline $\mathrm{SO}_{4}$ & 2.5180 & $.2888 \times 10^{-1}$ & -.2209 & -.2006 & $.3031 \times 10^{-1}$ & .1248 & .890 & .103 & 86 \\
\hline $\mathrm{Cl}$ & 1.4965 & $.5568 \times 10^{-1}$ & -.2590 & -.1467 & $.4525 \times 10^{-1}$ & .1355 & .845 & .127 & 88 \\
\hline TDS & 2.8561 & .1368 & -.1227 & -.1392 & $-.5930 \times 10^{-1}$ & $.5637 \times 10^{-1}$ & .855 & .066 & 88 \\
\hline
\end{tabular}

09224700 Blacks Fork near Little America, Wyo., 1970-75 water years

\begin{tabular}{llllllllll}
\hline $\mathrm{Ca}$ & 2.1897 & $-0.3005 \times 10^{-1}$ & -0.2452 & $-0.8708 \times 10^{-1}$ & $0.1222 \times 10^{-1}$ & 0.1432 & 0.778 & 0.087 & 61 \\
$\mathrm{Mg}$ & 1.9720 & -.3323 & -.3435 & -.1506 & .1459 & .1844 & .894 & .082 & 62 \\
$\mathrm{Na}$ & 2.5947 & -.6160 & -.4195 & -.1768 & .2907 & .2250 & .817 & .168 & 62 \\
$\mathrm{~K}$ & .7172 & -.3418 & -.3822 & $-.3461 \times 10^{-1}$ & .1374 & .1560 & .661 & .078 & 55 \\
$\mathrm{HCO}_{3}$ & 2.5747 & .2151 & -.3399 & $-.7689 \times 10^{-1}$ & $-.8641 \times 10^{-1}$ & .1328 & .759 & .061 & 62 \\
$\mathrm{SO}_{4}$ & 3.2412 & -.4122 & -.2117 & -.2758 & .1868 & .1505 & .903 & .115 & 54 \\
$\mathrm{Cl}$ & 2.1541 & -.5409 & -.3045 & -.1707 & .2657 & .1348 & .770 & .153 & 55 \\
$\mathrm{TDS}$ & 3.4221 & -.2466 & -.1394 & -.2064 & .1164 & $.9722 \times 10^{-1}$ & .886 & .092 & 55
\end{tabular}

09259700 Little Snake River near Baggs, Wyo., 1965-74 water years

\begin{tabular}{|c|c|c|c|c|c|c|c|c|c|}
\hline $\mathrm{Ca}$ & 1.6052 & -0.3896 & $-0.4413 \times 10^{-1}$ & $0.8984 \times 10^{-2}$ & 0.2174 & $0.2892 \times 10^{-1}$ & 0.895 & 0.078 & 81 \\
\hline Mg & 1.1950 & -.7907 & -.1716 & $-.4597 \times 10^{-1}$ & .3869 & $.7229 \times 10^{-1}$ & .844 & .177 & 81 \\
\hline $\mathrm{Na}$ & 1.9928 & -.8096 & .1733 & -.2087 & .3709 & $-.5973 \times 10^{-1}$ & .952 & .134 & 81 \\
\hline $\mathrm{K}$ & .4759 & -.4543 & $.6136 \times 10^{-1}$ & $-.5436 \times 10^{-1}$ & .2002 & $-.3844 \times 10^{-1}$ & .792 & .126 & 80 \\
\hline $\mathrm{HCO}_{3}$ & 2.4537 & -.2912 & -.1615 & $-.8414 \times 10^{-1}$ & .1598 & $.8360 \times 10^{-1}$ & .952 & .061 & 81 \\
\hline $\mathrm{SO}_{4}$ & 1.9059 & -1.027 & .3184 & $-.4803 \times 10^{-1}$ & .4940 & -.1370 & .920 & .156 & 80 \\
\hline $\mathrm{C} 1$ & 1.7546 & -.6815 & .2016 & -.3413 & .2858 & $-.5831 \times 10^{-1}$ & .924 & .203 & 79 \\
\hline TDS & 2.704 & -.5203 & .1653 & -.1190 & .2498 & $-.7013 \times 10^{-1}$ & .961 & .075 & 80 \\
\hline
\end{tabular}


Table 4.--Regression results, concentration versus specific conductance

[S. J. Rucker IV, written commun., 1977]

$$
\mathrm{TDS}=\mathrm{E}+\mathrm{FK}
$$

where

$$
\begin{aligned}
\text { TDS } & =\text { Dissolved solids, in milligrams per liter }, \\
\mathrm{E} & =\text { Intercept, in milligrams per liter }, \\
\mathrm{F} & =\text { Slope, and } \\
\mathrm{K} & =\text { Specific conductance, in micromhos per centimeter } \\
& \text { at } 25^{\circ} \mathrm{C} .
\end{aligned}
$$

\begin{tabular}{lccccc}
\hline Station & E & F & r & SE & N \\
\hline 09209400 & -12.9 & 0.645 & 0.987 & 9.6 & 129 \\
09211200 & -23.6 & .657 & .942 & 10.4 & 83 \\
09217000 & -57.5 & .760 & .993 & 21.1 & 149 \\
09222000 & -18.4 & .856 & .993 & 86.3 & 150 \\
09224700 & -88.8 & .772 & .995 & 52.6 & 154 \\
\hline
\end{tabular}

$$
r=\text { Correlation coefficient. }
$$

$\mathrm{SE}=$ Standard error of estimate, in milligrams per liter.

$\mathrm{N}=$ Number of paired values. 

